\title{
Synthesis and X-ray structures of hydridotris(1-pyrazolyl)borate carbonyl complexes of ruthenium
}

\author{
Kom-Bei Shiu ${ }^{a} *$, Jiun-Yu Chen a, Shin-Jay Yu ${ }^{a}$, Sue-Lein Wang ${ }^{b}$, Fen-Ling Liao ${ }^{\text {b }}$ \\ $\mathrm{Yu}$ Wang ${ }^{\mathrm{c}}$, Gene-Hsiang Lee ${ }^{\mathrm{c}}$ \\ ${ }^{a}$ Department of Chemistry, National Cheng Kung University, Tainan 701, Taiwan \\ ${ }^{\mathrm{b}}$ Instrument Center, National Tsing-Hua University, Hsinchu 300, Taiwan \\ ' Instrument Center, National Taiwan University, Taipei 106, Taiwan
}

Received 27 August 2001; received in revised form 24 October 2001; accepted 30 October 2001

\begin{abstract}
A series of new hydridotris(1-pyrazolyl)borate (Tp) carbonyl complexes of ruthenium were synthesized. Treatment of $\left[\mathrm{TpRu}(\mathrm{CO})_{2} \mathrm{X}\right]\left(\mathrm{X}=\mathrm{Br}\right.$, I) with $\mathrm{Me}_{3} \mathrm{NO}$ in $\mathrm{MeCN}$ afforded $[\mathrm{TpRu}(\mathrm{CO})(\mathrm{NCMe}) \mathrm{X}](\mathrm{X}=\mathrm{Br}(\mathbf{1}), \mathrm{I}(\mathbf{2}))$. The reactions of 1 and 2 with either neutral isocyanides or anionic dialkyldithiocarbamates to produce $[\mathrm{TpRu}(\mathrm{CO})(\mathrm{CNR}) \mathrm{X}]\left(\mathrm{X}=\mathrm{Br}, \mathrm{R}=\mathrm{PhCH}_{2}(\mathbf{3})\right.$; $\left.\mathrm{X}=\mathrm{Br}, \mathrm{R}={ }^{t} \mathrm{Bu}(\mathbf{4}) ; \mathrm{X}=\mathrm{I}, \mathrm{R}=\mathrm{PhCH}_{2}(\mathbf{5}) \mathrm{X}=\mathrm{I}, \mathrm{R}={ }^{t} \mathrm{Bu}(\mathbf{6})\right)$ and $\left[\mathrm{TpRu}(\mathrm{CO})\left(\eta^{2}-\mathrm{S}_{2} \mathrm{CNR}_{2}\right)\right](\mathrm{R}=\mathrm{Me}(7)$, Et (8)), respectively. Compounds 1 and 2 reacts with $\mathrm{RSH}-\mathrm{Et}_{3} \mathrm{~N}$ in THF or 1,2-dimethoxyethane at reflux to give mono- and dithiolato diruthenium products, (cis) $-\left[\mathrm{Tp}_{2} \mathrm{Ru}_{2}(\mathrm{CO})_{2}(\mu-\mathrm{X})(\mu-\mathrm{SR})\right]\left(\mathrm{X}=\mathrm{I}, \mathrm{R}={ }^{i} \operatorname{Pr}(\mathbf{1 1}) ; \mathrm{X}=\mathrm{Br}, \mathrm{R}={ }^{t} \mathrm{Bu}\right.$ (13); $\mathrm{X}=\mathrm{I}, \mathrm{R}={ }^{t} \mathrm{Bu}$ (14)), (trans, anti-1)-

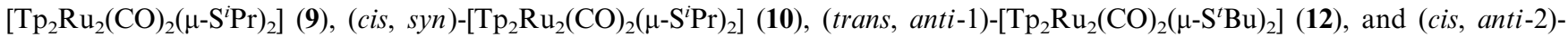
$\left[\mathrm{Tp}_{2} \mathrm{Ru}_{2}(\mathrm{CO})_{2}(\mu-\mathrm{S} \operatorname{Pr})\left(\mu-\mathrm{S}^{t} \mathrm{Bu}\right)\right](\mathbf{1 5})$. Compound 11 reacts with $\mathrm{Me}_{3} \mathrm{NO}$ to form stereo- and chemospecifically the first diruthenium sulfenate, $($ cis $)-\left[\mathrm{Tp}_{2} \mathrm{Ru}_{2}(\mathrm{CO})_{2}(\mu-\mathrm{I})\left(\mu-\mathrm{S}(\mathrm{O})^{i} \mathrm{Pr}\right)\right]$ (16) with the $\mathrm{S}=\mathrm{O}$ bond at the endo position with respect to carbonyls. Structures 8, 9, 10, 12, 14, 15, and 16 are described. (C) 2002 Elsevier Science B.V. All rights reserved.
\end{abstract}

Keywords: Ruthenium; Hydridotris(1-pyrazolyl)borate; Thiolates; Isocyanides; Dialkyl dithiocarbamates; Carbonyl

\section{Introduction}

Since the discovery of the pyrazolylborate ligands by Trofimenko in 1966 [1], an extensive transition-metal chemistry that utilizes these ligands has emerged [2]. Due to the apparent similarity in coordination and electronic structure to the cyclopentadienyl $(\mathrm{Cp})$ ligand, much chemistry developed with the hydridotris(L-pyrazolyl)borate (Tp) ligand has involved compounds whose $\mathrm{Cp}$ analogues were well established. Despite these similarities, there were for many years few and scattered reports of mixed-ligand complexes of ruthenium containing a Tp ligand, a carbonyl ligand, and other ligands [3], in contrast with numerous corresponding $\mathrm{CpRu}(\mathrm{CO})$ complexes [4]. The obvious reason is the lack of $\mathrm{TpRu}(\mathrm{CO})$ starting compounds. Previous attempts, as well as our own attempts (vide infra) to

* Corresponding author. Fax: + 886-6-2740552.

E-mail address: kbshiu@mail.ncku.edu.tw (K.-B. Shiu). synthesize the mixed-ligand $\mathrm{Ru}$ compounds using $\left[\mathrm{TpRu}(\mathrm{CO})_{2} \mathrm{X}\right](\mathrm{X}=\mathrm{Br}, \mathrm{I})$ [3a,3d] were frustrated by low or no conversion. However, we wish to report here that $[\mathrm{TpRu}(\mathrm{CO})(\mathrm{MeCN}) \mathrm{X}](\mathrm{X}=\mathrm{Br}(\mathbf{1}), \mathrm{I}(\mathbf{2}))$ can be obtained readily and serve as a better starting material, leading to a series of new $\mathrm{TpRu}(\mathrm{CO})$ products.

\section{Results and discussion}

\subsection{Preparation of $[T p R u(C O)(M e C N) X](X=B r(\mathbf{1})$, I (2))}

The Tp ligand, with its steric bulk (cone angle $180^{\circ}$ ) and unique electronic properties [5], is known to bias formation of the octahedral six-coordinate complexes of transition-metal atoms. It is hence not unexpected that no genuine seven-coordinate $\mathrm{TpRu}$ compounds were described in the literature [3,6]. This propensity of the ligand apparently accounts for the observed poor 
reactivity of $\left[\mathrm{TpRu}(\mathrm{CO})_{2} \mathrm{X}\right](\mathrm{X}=\mathrm{Br}$, I) toward various nucleophiles even under forced conditions. Thus, it usually allows only a partial conversion (ca. 30-50\%), shown in the sequentially measured solution IR spectra, from $\left[\mathrm{TpRu}(\mathrm{CO})_{2} \mathrm{X}\right]$ into other derivatives, even when the reaction mixture of $\left[\mathrm{TpRu}(\mathrm{CO})_{2} \mathrm{X}\right]$ and nucleophiles in $\mathrm{MeCN}$ was heated at $82{ }^{\circ} \mathrm{C}$ for 3 days. Unfortunately, there were for many years no reports in the literature concerning any other $\{\mathrm{TpRu}(\mathrm{CO})\}$ complexes as good starting material [3]. We have now found that employment of $[\mathrm{TpRu}(\mathrm{CO})(\mathrm{MeCN}) \mathrm{X}](\mathrm{X}=\mathrm{Br}$ (1), I (2)), prepared in a high yield from decarbonylation of $\left[\mathrm{TpRu}(\mathrm{CO})_{2} \mathrm{X}\right]$ with $\mathrm{Me}_{3} \mathrm{NO}$ in $\mathrm{MeCN}$, as the starting compounds can allow a complete conversion into the derived products. Apparently compounds $\mathbf{1}$ and $\mathbf{2}$ are the lightly stabilized complexes [7], and can serve as a good starting material leading to other substituted compounds.

\subsection{Formation of monomeric $T p R u(C O)$ complexes}

No apparent reaction between $\left[\mathrm{TpRu}(\mathrm{CO})_{2} \mathrm{X}\right]$ and neutral alkyl isocyanides in $\mathrm{MeCN}$ was observed, monitored by sequential solution IR spectra, even under reflux for a week. However, treatment of $\mathbf{1}$ and $\mathbf{2}$ with a slight excess of RNC under reflux for $12 \mathrm{~h}$ gave the expected complexes $[\mathrm{TpRu}(\mathrm{CO})(\mathrm{CNR}) \mathrm{X}](\mathrm{X}=\mathrm{Br}, \mathrm{R}=$ $\mathrm{PhCH}_{2}$ (3), ${ }^{t} \mathrm{Bu}(4) ; \mathrm{X}=\mathrm{I}, \mathrm{R}=\mathrm{PhCH}_{2}$ (5), $\left.{ }^{t} \mathrm{Bu}(6)\right)$ in $60-70 \%$ yield. Likewise, reaction between 2 and anionic dialkyldithiocarbamate produced as expected $\left[\mathrm{TpRu}(\mathrm{CO})\left(\eta^{2}-\mathrm{S}_{2} \mathrm{CNR}_{2}\right)\right]\left(\mathrm{R}^{\prime}=\mathrm{Me}(7)\right.$, Et $\left.(\mathbf{8})\right)$ in a satisfactory yield within a reasonable period of time.

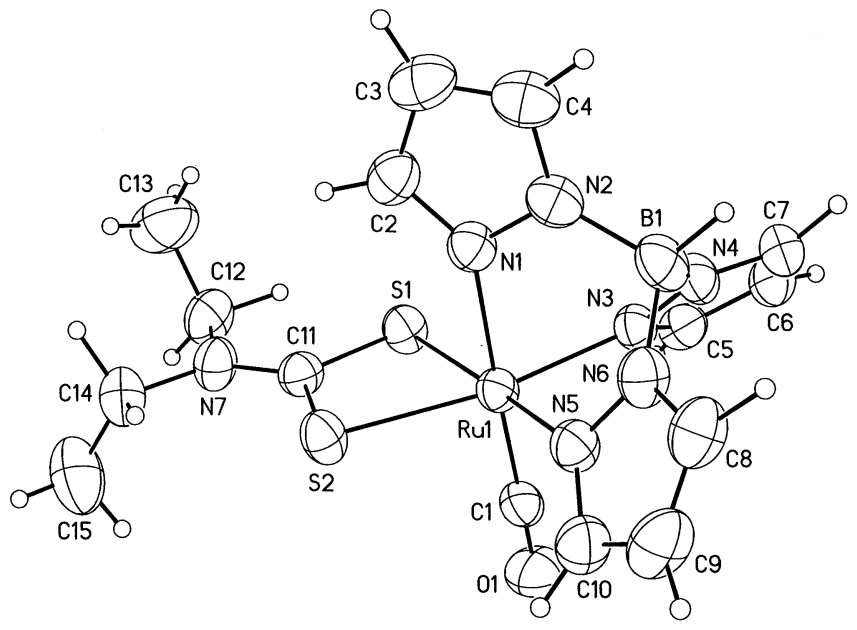

Fig. 1. ORTEP drawing of $\left[\mathrm{TpRu}(\mathrm{CO})\left(\eta^{2}-\mathrm{S}_{2} \mathrm{CNEt}_{2}\right)\right]$ (8). Thermal ellipsoids are drawn at the $50 \%$ probability level. Selected bond distances $(\AA)$ and angles $\left({ }^{\circ}\right)$ are as follows: $\mathrm{Ru}(1)-\mathrm{C}(1), 1.834(3)$; $\mathrm{Ru}(1)-\mathrm{N}(1), 2.158(2) ; \mathrm{Ru}(1)-\mathrm{N}(3), 2.101(2) ; \mathrm{Ru}(1)-\mathrm{N}(5), 2.113(2)$; $\mathrm{Ru}(1)-\mathrm{S}(1), 2.3811(7) ; \mathrm{Ru}(1)-\mathrm{S}(2), 2.4013(7) ; \mathrm{S}(1)-\mathrm{C}(11), 1.725(3)$; $\mathrm{S}(2)-\mathrm{C}(11), \quad 1.724(3) ; \quad \mathrm{C}(11)-\mathrm{N}(7), \quad 1.329(3) ; \quad \mathrm{C}(1)-\mathrm{O}(1), 1.146(3)$; $\mathrm{S}(1)-\mathrm{Ru}(1)-\mathrm{S}(2), 72.93(2) ; \mathrm{Ru}(1)-\mathrm{C}(1)-\mathrm{O}(1), 178.7(2) ; \mathrm{S}(1)-\mathrm{C}(11)$ $\mathrm{S}(2), 123.9(2)$.
The monomeric feature of $\mathbf{8}$ was also confirmed by its crystal structure (Fig. 1). The $\mathrm{C}-\mathrm{N}$ distance of the coordinated diethyldithiocarbamate, $\mathrm{d}(\mathrm{C}(11)-\mathrm{N}(7))=$ $1.329(3) \AA$, is within the typical range of $1.31-1.36 \AA$ [8] for containing a partial double-bond character, and the distance is found compatible with the $\mathrm{C}-\mathrm{N}$ stretching frequency of $1501 \mathrm{~cm}^{-1}$ measured in $\mathrm{CH}_{2} \mathrm{Cl}_{2}$.

\subsection{Formation of dimeric $T p R u(C O)$ complexes}

Prior to studying the reactions between $[\mathrm{TpRu}(\mathrm{CO})$ $(\mathrm{MeCN}) \mathrm{X}]$ and thiolates, it was expected to obtain dimeric $\left\{\mathrm{Tp}_{2} \mathrm{Ru}_{2}\right\}$ products with exclusively trans-disposed Tp ligands, based on the steric bulk of this ligand. However, to our surprise, seven different products were obtained with five cis and two trans compounds, containing one and two thiolato bridges: (cis) $-\left[\mathrm{Tp}_{2} \mathrm{Ru}_{2}(\mathrm{CO})(\mu-\mathrm{X})(\mu-\mathrm{SR})\right] \quad\left(\mathrm{X}=\mathrm{I}, \quad \mathrm{R}={ }^{i} \operatorname{Pr} \quad\right.$ (11); $\mathrm{X}=\mathrm{Br}, \mathrm{R}={ }^{t} \mathrm{Bu}(\mathbf{1 3}) ; \mathrm{X}=\mathrm{I}, \mathrm{R}={ }^{t} \mathrm{Bu}(\mathbf{1 4})$ ), (trans, anti-

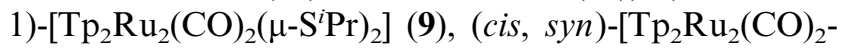

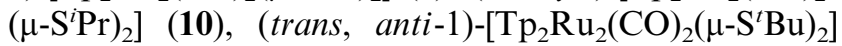

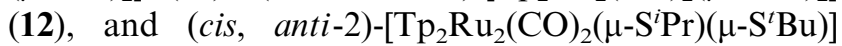
(15). For the compounds containing two thiolato bridges, except the common syn orientation [9], there are two types of anti orientations: anti-1 for the geometry containing one thiolato $\mathrm{R}$ group above plane $\mathrm{Ru}_{2} \mathrm{~S}_{2}$ and the other group below, and anti-2 for the geometry with one thiolato $\mathrm{R}$ group below plane $\mathrm{Ru}_{2} \mathrm{~S}_{2}$ and the other group coplanar with $\mathrm{Ru}_{2} \mathrm{~S}_{2}$ (Chart 1). $\left[\mathrm{Tp}_{2} \mathrm{Ru}_{2}(\mathrm{CO})_{2}(\mu-\mathrm{Br})\left(\mu-\mathrm{S}^{i} \mathrm{Pr}\right)\right]$ was not isolated in the reaction between 1 and ${ }^{i} \mathrm{PrSH}-\mathrm{Et}_{3} \mathrm{~N}$. Clearly with the exception of the steric effect of the Tp ligand, the formation of different products is also dependent on the effect of the halo ligand, $\mathrm{X}$, of $[\mathrm{TpRu}(\mathrm{CO})$ $(\mathrm{MeCN}) \mathrm{X}]$ and that of the thiolato $\mathrm{R}$ group. Using a thiol reagent with a bulkier ${ }^{t} \mathrm{Bu}$ group, or using $\mathbf{2}$ with a larger iodo ligand, mono-thiolato products $\left[\mathrm{Tp}_{2} \mathrm{Ru}_{2}(\mathrm{CO})_{2}(\mu-\mathrm{X})(\mu-\mathrm{SR})\right]\left(\mathrm{X}=\mathrm{I}, \mathrm{R}={ }^{i} \operatorname{Pr}(\mathbf{1 1}) ; \mathrm{X}=\mathrm{Br}\right.$, $\left.\mathrm{R}={ }^{t} \mathrm{Bu}(\mathbf{1 3}) ; \mathrm{X}=\mathrm{I}, \mathrm{R}={ }^{t} \mathrm{Bu}(\mathbf{1 4})\right)$ were then observed. The geometries of these mono-thiolato complexes are similar to each other: each displays two carbonyl stretching bands in the IR spectrum, and one set of six doublets in an intensity ratio of 1:1:1:1:1:1 for hydrogen nuclei at the 3- and 5-positions of the pyrazolyl rings of the Tp ligand and a set of three triplets in an intensity ratio of 1:1:1 for those at the 4-positions in the ${ }^{1} \mathrm{H}$ NMR spectrum. The crystal structure of $\mathbf{1 4}$ was determined, and two Tp ligands were found to adopt the cis positions (Fig. 2). Sum in the metallacycle $\mathrm{Ru}(1) / \mathrm{S}(1) /$ $\mathrm{Ru}(2) / \mathrm{I}$ is $345.50^{\circ}$, deviated largely from the theoretical value of $360^{\circ}$ required for planar four-membered ring. It indicates that the four atoms, $\mathrm{Ru}_{2} \mathrm{SX}(\mathrm{X}=\mathrm{I}$, in 14), are not coplanar. Apparently, $[\mathrm{TpRu}(\mathrm{CO})(\mathrm{MeCN}) \mathrm{X}]$ reacted with $\mathrm{RSH}-\mathrm{Et}_{3} \mathrm{~N}$ to form an intermediate $[\mathrm{TpRu}(\mathrm{CO})(\mathrm{SR})]$ first, and either dimerization of this intermediate or a subsequent reaction between [TpRu- 


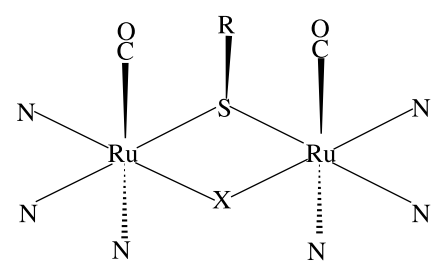

(cis)

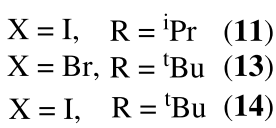

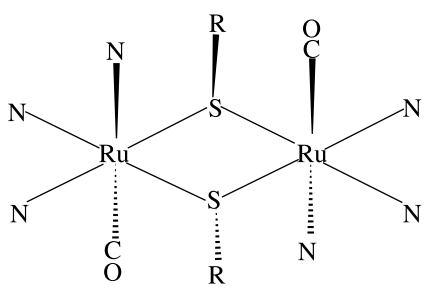

\begin{tabular}{c} 
(trans, anti-1) \\
\hline $\mathrm{R}={ }^{\mathrm{i}} \mathrm{Pr} \quad(\mathbf{9})$ \\
$\mathrm{R}={ }^{\mathrm{t}} \mathrm{Bu}$
\end{tabular}

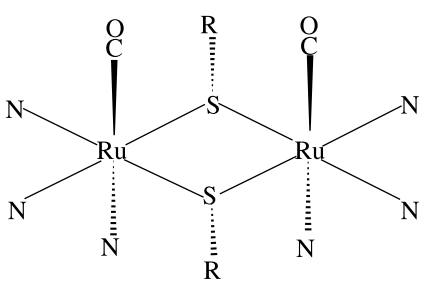

(cis, syn)

$\mathrm{R}={ }^{\mathrm{i}} \operatorname{Pr}(\mathbf{1 0})$

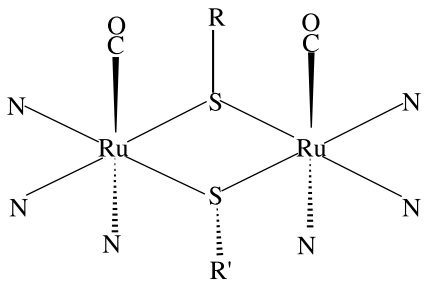

(cis, anti-2)

$\mathrm{R}={ }^{\mathrm{t}} \mathrm{Bu}, \mathrm{R}^{\prime}={ }^{\mathrm{i}} \operatorname{Pr}(\mathbf{1 5})$

Chart 1.

$(\mathrm{CO})(\mathrm{SR})]$ and $[\mathrm{TpRu}(\mathrm{CO})(\mathrm{MeCN}) \mathrm{X}]$ then took place to form $\left[\mathrm{Tp}_{2} \mathrm{Ru}_{2}(\mathrm{CO})_{2}(\mu-\mathrm{SR})_{2}\right]$ and $\left[\mathrm{Tp}_{2} \mathrm{Ru}_{2}(\mathrm{CO})_{2}(\mu-\right.$ $\mathrm{X})(\mu-\mathrm{SR})]$ (Scheme 1).

The reaction of 1 or 2 with ${ }^{i} \mathrm{PrSH}-\mathrm{Et}_{3} \mathrm{~N}$ was heated in either THF or 1,2-dimethoxyethane under reflux, giving several products. Two typical reactions as shown in the Section 3 produced (trans, anti-1)- $\left[\mathrm{Tp}_{2} \mathrm{Ru}_{2}-\right.$

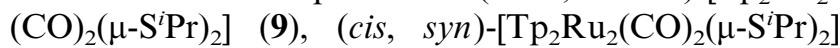

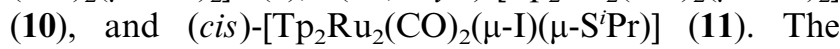
crystal structures of $\mathbf{9}$ (Fig. 3) and $\mathbf{1 0}$ (Fig. 4) were also determined by X-ray diffraction methods to confirm the (trans, anti-1) and (cis, syn-1) geometries assigned for 9 and 10, respectively. Sum in the metallacycle $\mathrm{Ru}(1) /$ $\mathrm{S}(1 \mathrm{~A}) / \mathrm{Ru}(1 \mathrm{~A}) / \mathrm{S}(1)$ is $360^{\circ}$ in $\mathbf{9}$, indicating that unlike $\mathrm{Ru}_{2} \mathrm{SX}$ in 14 (Fig. 2), the four atoms, $\mathrm{Ru}_{2} \mathrm{~S}_{2}$ in 9 (Fig. 3) are coplanar, with one thiolato $R$ group above this plane and the other below, probably due to the fact that this structure contains a crystallographically imposed inversion center. Although, structure $\mathbf{1 0}$ has a crystallographically imposed mirror plane containing two sulfur atoms, $\mathrm{S}(1)$ and $\mathrm{S}(2)$, and two carbon atoms, $\mathrm{C}(11)$ and $\mathrm{C}(13)$, the four $\mathrm{Ru}_{2} \mathrm{~S}_{2}$ atoms (i.e. $\mathrm{Ru}(1)$, $\mathrm{Ru}(1 \mathrm{~A}), \mathrm{S}(1)$, and $\mathrm{S}(2))$, in $\mathbf{1 0}$ are not coplanar with sum in the metallacycle $\mathrm{Ru}(1) / \mathrm{S}(2) / \mathrm{Ru}(1 \mathrm{~A}) / \mathrm{S}(1)$ of $356.94^{\circ}$.

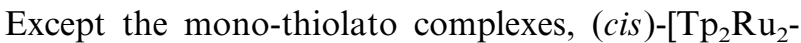
$\left.(\mathrm{CO})_{2}(\mu-\mathrm{Br})\left(\mu-\mathrm{S}^{t} \mathrm{Bu}\right)\right]$ (13) and (cis)-[ $\mathrm{Tp}_{2} \mathrm{Ru}_{2}(\mathrm{CO})_{2}(\mu-$

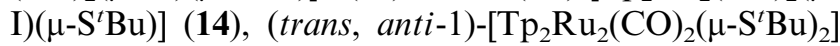
(12) was separated successfully from the reactions of 1 or 2 with ${ }^{t} \mathrm{BuSH}-\mathrm{Et}_{3} \mathrm{~N}$. Compound 12 shows similar features in both IR and ${ }^{1} \mathrm{H}-\mathrm{NMR}$ spectra to compound 9. Like 9, compound $\mathbf{1 2}$ also adopts a (trans, anti-1) geometry as confirmed by X-ray diffraction methods.

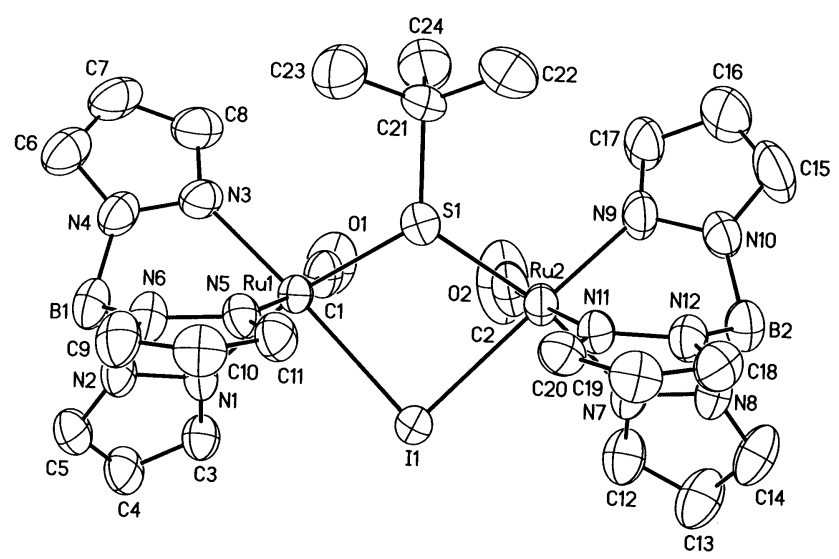

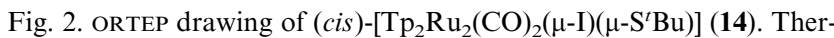
mal ellipsoids are drawn at the $50 \%$ probability level. Hydrogen atoms are omitted for clarity. Selected bond distances $(\AA)$ and angles $\left({ }^{\circ}\right)$ are as follows: $\mathrm{Ru}(1)-\mathrm{C}(1), 1.844(8) ; \mathrm{Ru}(1)-\mathrm{N}(1), 2.102(6)$; $\mathrm{Ru}(1)-\mathrm{N}(3), 2.099(6) ; \mathrm{Ru}(1)-\mathrm{N}(5), 2.148(6) ; \mathrm{Ru}(1)-\mathrm{S}(1), 2.423(2)$; $\mathrm{Ru}(1)-\mathrm{I}(1), 2.7288(7) ; \mathrm{C}(1)-\mathrm{O}(1), 1.115(10) ; \mathrm{Ru}(2)-\mathrm{C}(2), 1.825(9)$; $\mathrm{Ru}(2)-\mathrm{N}(7), 2.089(6) ; \mathrm{Ru}(2)-\mathrm{N}(9), 2.100(7) ; \mathrm{Ru}(2)-\mathrm{N}(11), 2.173(6)$; $\mathrm{Ru}(2)-\mathrm{S}(1), 2.452(2) ; \mathrm{Ru}(2)-\mathrm{I}(1), 2.7338(7) ; \mathrm{C}(2)-\mathrm{O}(2), 1.152(12)$; $\mathrm{S}(1)-\mathrm{C}(21), 1.828(8) ; \mathrm{S}(1)-\mathrm{Ru}(1)-\mathrm{I}(1), 76.07(5) ; \mathrm{Ru}(1)-\mathrm{I}(1)-\mathrm{Ru}(2)$, 89.60(2); I(1)-Ru(2)-S(1), 75.53(5); $\mathrm{Ru}(2)-\mathrm{S}(1)-\mathrm{Ru}(1), \quad 104.30(8)$; $\mathrm{Ru}(1)-\mathrm{C}(1)-\mathrm{O}(1), 173.2(8) ; \mathrm{Ru}(2)-\mathrm{C}(2)-\mathrm{O}(2), 171.4(9)$. 


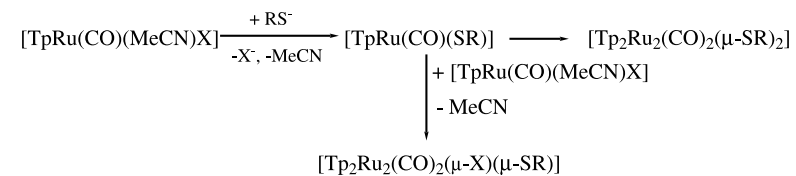

Scheme 1.

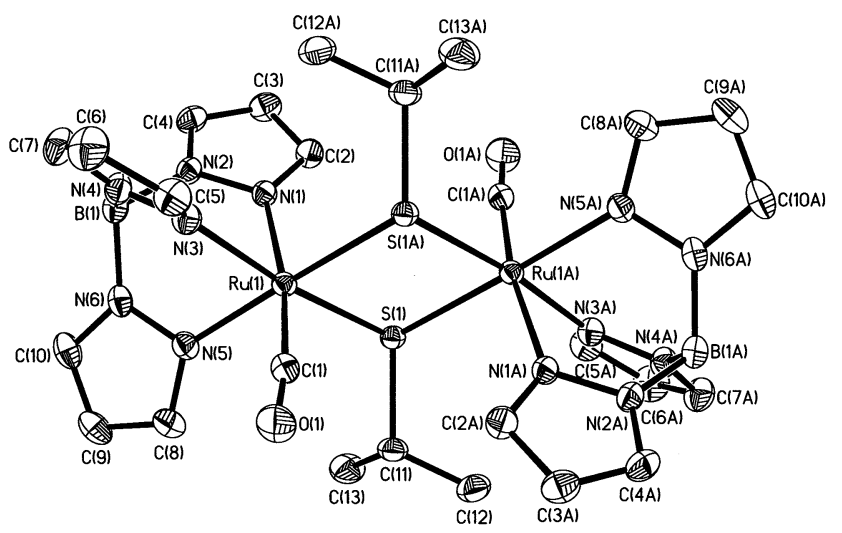

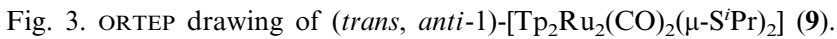
Thermal ellipsoids are drawn at the $30 \%$ probability level. Hydrogen atoms are omitted for clarity. Selected bond distances $(\AA)$ and angles $\left(^{\circ}\right)$ are as follows: $\mathrm{Ru}(1)-\mathrm{C}(1), 1.826(3) ; \mathrm{Ru}(1)-\mathrm{N}(1), 2.165(2)$; $\mathrm{Ru}(1)-\mathrm{N}(3), 2.104(3) ; \mathrm{Ru}(1)-\mathrm{N}(5), 2.127(3) ; \mathrm{Ru}(1)-\mathrm{S}(1), 2.4264(7) ;$ $\mathrm{S}(1)-\mathrm{C}(11), 1.858(3) ; \mathrm{C}(1)-\mathrm{O}(1), 1.152(4) ; \mathrm{S}(1)-\mathrm{Ru}(1)-\mathrm{S}(1 \mathrm{~A}), 79.90(3)$; $\mathrm{Ru}(1)-\mathrm{S}(1)-\mathrm{Ru}(1 \mathrm{~A}), 100.10(3) ; \mathrm{Ru}(1)-\mathrm{C}(1)-\mathrm{O}(1), 172.6(3)$.

The asymmetric unit of the single crystal used contains one half dinuclear molecule for 9 (Fig. 3), but two such half molecules, 12A and 12B, for 12. Both 9 and $\mathbf{1 2}$ contain a crystallographically imposed inversion center. Although structure 12A is similar to structure 12B, two methyl groups of the ${ }^{t} \mathrm{Bu}$ group in 12B were found to be disordered in two positions with an occupancy ratio of 0.726:0.274. Molecule 12A was drawn in Fig. 5. The fact that the ${ }^{t} \mathrm{Bu}$ singlet for $\mathbf{1 4}$ or $\mathbf{1 3}$ is at the further upfield position, with $\delta 0.88$ for $\mathbf{1 4}$ and $\delta 1.02$ for $\mathbf{1 3}$ relative to that of $\delta 1.74$ for $\mathbf{1 2}$, is probably caused by the different shielding ring-current effect of the nearby pyrazolyl moieties of the Tp ligands.

To obtain some diruthenium complexes with mixed thiolato ligands, the reaction of 1 with ${ }^{i} \mathrm{PrSH},{ }^{t} \mathrm{BuSH}$, and $\mathrm{Et}_{3} \mathrm{~N}$ was also carried out in 1,2-dimethoxyethane. Since a ${ }^{t} \mathrm{Bu}$ group is much larger than an ${ }^{i} \operatorname{Pr}$ group, more ${ }^{t} \mathrm{BuSH}$ than ${ }^{i} \mathrm{PrSH}$ was used in the reaction. Except three homo-dithiolato compounds of 9, 10, and 12, only one hetero-dithiolato product $\left[\mathrm{Tp}_{2} \mathrm{Ru}_{2}(\mathrm{CO})_{2}(\mu-\right.$ $\left.\left.\mathrm{S}^{i} \mathrm{Pr}\right)\left(\mu-\mathrm{S}^{t} \mathrm{Bu}\right)\right](\mathbf{1 5})$ was isolated. The crystal structure of 15 was determined and found to contain a crystallographically imposed mirror plane consisting of atoms $\mathrm{S}(1), \mathrm{S}(2), \mathrm{C}(11), \mathrm{C}(13)$ and $\mathrm{C}(15)$ (Fig. 6). It is worthy to note that structure $\mathbf{1 5}$ adopts a unique (cis, anti-2) geometry with a large $\mathrm{R}$ group, ${ }^{t} \mathrm{Bu}$, rather than a small one, ${ }^{i} \mathrm{Pr}$, at a position close to the plane $\mathrm{Ru}_{2} \mathrm{~S}_{2}$ (Fig. 6). Like structure $\mathbf{1 0}$, the four atoms, $\mathrm{Ru}_{2} \mathrm{~S}_{2}$, in structure $\mathbf{1 5}$ are not coplanar with sum in the metallacycle $\mathrm{Ru}(1) /$ $\mathrm{S}(1) / \mathrm{Ru}(1 \mathrm{~A}) / \mathrm{S}(2)$ of $351.03^{\circ}$. In order to find an explanation for $\mathbf{1 5}$ to adopt such a geometry, structures, $\mathbf{9}$, 10, 12, 14, and 15 were compared with each other again, and a unique feature was then rediscovered as shown in Scheme 2. If the carbon and oxygen atoms of each carbonyl in these structures, the ligated $\mathrm{Ru}$ atom, and one trans-pyrazolyl nitrogen atom are connected in one imaginary line segment, two such segments in $\mathbf{9}$ and 12 are found to be almost parallel to each other, but the two segments in 10, 14, and $\mathbf{1 5}$ are not, forming a small angle of $2.6^{\circ}$ in $\mathbf{1 0}, 8.0^{\circ}$ in $\mathbf{1 4}$ and $4.4^{\circ}$ in $\mathbf{1 5}$. Apparently, the molecular strain resulting from repulsive nonbonded interactions between a bulky Tp ligand and a thiolato group (or a halo group) cannot be relieved in a

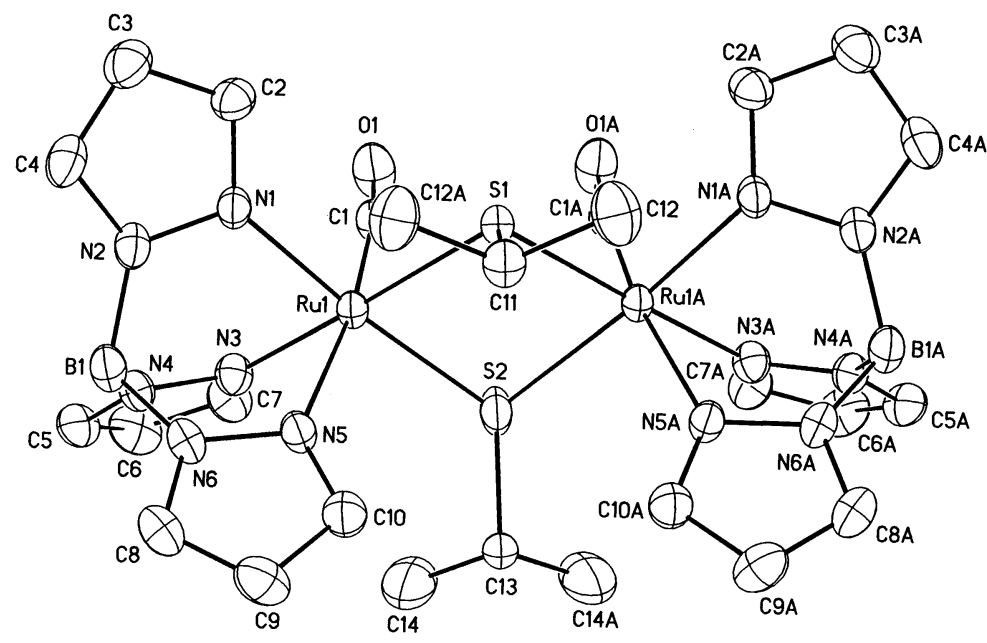

Fig. 4. ORTEP drawing of (cis, syn)-[ $\left.\mathrm{Tp}_{2} \mathrm{Ru}_{2}(\mathrm{CO})_{2}\left(\mu-\mathrm{S}^{i} \mathrm{Pr}\right)_{2}\right](\mathbf{1 0})$. Thermal ellipsoids are drawn at the $50 \%$ probability level. Hydrogen atoms are omitted for clarity. Selected bond distances $(\AA)$ and angles $\left(^{\circ}\right)$ are as follows: $\mathrm{Ru}(1)-\mathrm{C}(1), 1.820(6) ; \mathrm{Ru}(1)-\mathrm{N}(1), 2.098(4)$; $\mathrm{Ru}(1)-\mathrm{N}(3), 2.113(4)$; $\mathrm{Ru}(1)-\mathrm{N}(5), 2.192(4) ; \mathrm{Ru}(1)-\mathrm{S}(1), 2.4146(12) ; \mathrm{Ru}(1)-\mathrm{S}(2), 2.415(2) ; \mathrm{S}(1)-\mathrm{C}(11), 1.840(7) ; \mathrm{C}(1)-\mathrm{O}(1), \quad 1.155(7) ; \mathrm{S}(1)-\mathrm{Ru}(1)-\mathrm{S}(2)$, 80.49(6); $\mathrm{Ru}(1)-\mathrm{S}(1)-\mathrm{Ru}(1 \mathrm{~A}), 98.00(6) ; \mathrm{Ru}(1)-\mathrm{S}(2)-\mathrm{Ru}(1 \mathrm{~A}), 97.96(8) ; \mathrm{Ru}(1)-\mathrm{C}(1)-\mathrm{O}(1), 172.6(5)$. 


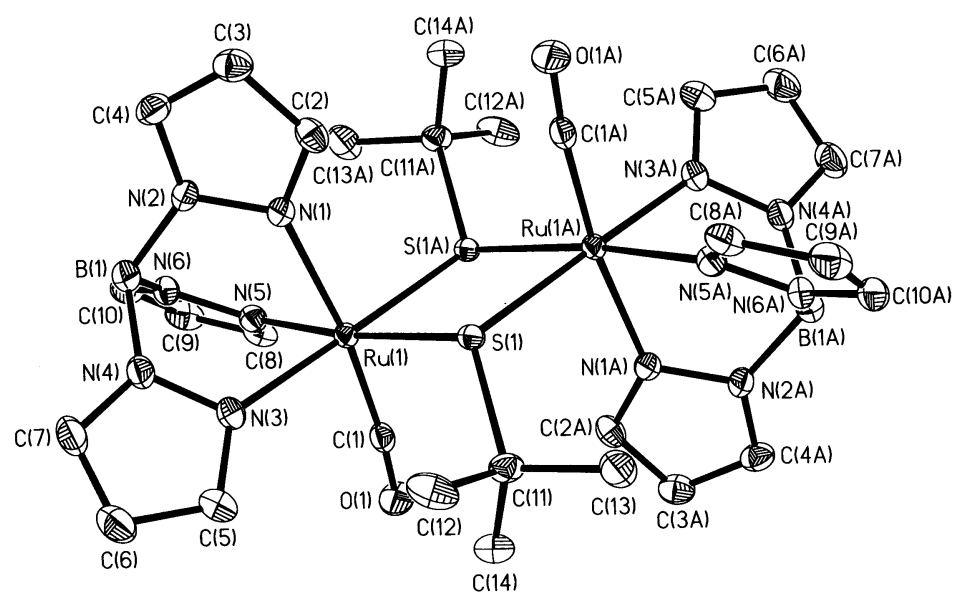

Fig. 5. ORTEP drawing of (trans, anti-1)-[T $\left.\mathrm{Tp}_{2} \mathrm{Ru}_{2}(\mathrm{CO})_{2}\left(\mu-\mathrm{S}^{t} \mathrm{Bu}\right)_{2}\right](\mathbf{1 2 A})$. Thermal ellipsoids are drawn at the $50 \%$ probability level. Hydrogen atoms are omitted for clarity. Selected bond distances $(\AA)$ and angles $\left({ }^{\circ}\right)$ are as follows: Ru(1)-C(1), 1.829(3); Ru(1)-N(1), 2.167(3); Ru(1)-N(3), 2.139(3); $\mathrm{Ru}(1)-\mathrm{N}(5), 2.107(3) ; \mathrm{Ru}(1)-\mathrm{S}(1), 2.4527(8) ; \mathrm{S}(1)-\mathrm{C}(11), 1.895(3) ; \mathrm{C}(1)-\mathrm{O}(1), 1.162(4) ; \mathrm{S}(1)-\mathrm{Ru}(1)-\mathrm{S}(1 \mathrm{~A}), 78.87(3) ; \mathrm{Ru}(1)-\mathrm{S}(1)-\mathrm{Ru}(1 \mathrm{~A}), 101.13(3)$; $\mathrm{Ru}(1)-\mathrm{C}(1)-\mathrm{O}(1), 173.3(3)$.

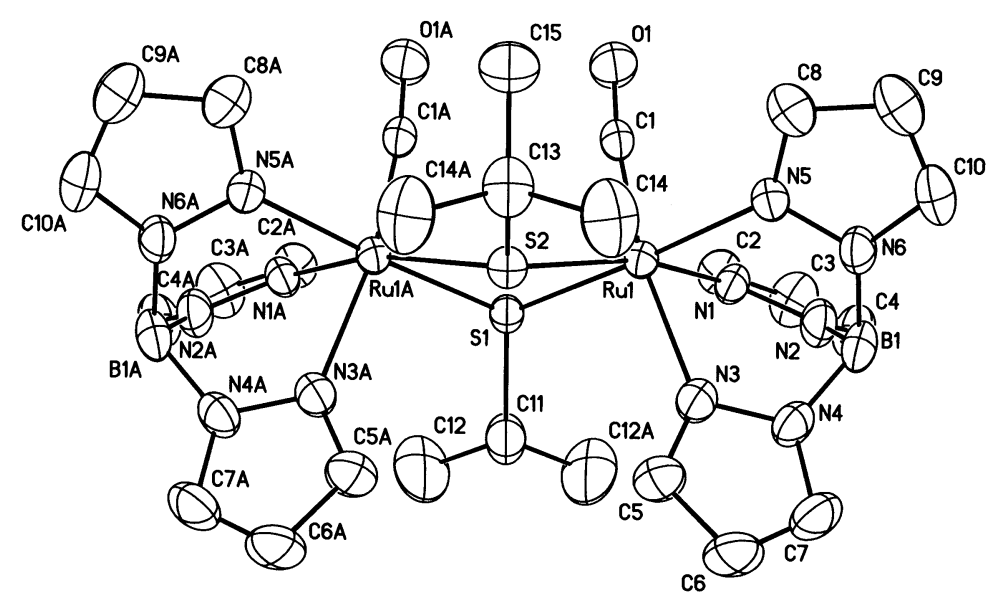

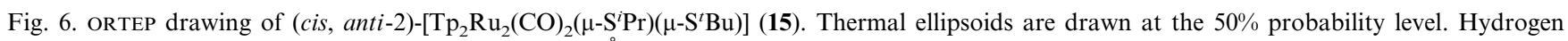
atoms are omitted for clarity. Selected bond distances $(\AA)$ and angles $\left(^{\circ}\right)$ are as follows: $\mathrm{Ru}(1)-\mathrm{C}(1), 1.817(5) ; \mathrm{Ru}(1)-\mathrm{N}(1), 2.103(4) ; \mathrm{Ru}(1)-\mathrm{N}(3)$, 2.186(4); $\mathrm{Ru}(1)-\mathrm{N}(5), 2.126(4) ; \mathrm{Ru}(1)-\mathrm{S}(1), 2.4222$ (11); Ru(1)-S(2), 2.4040(11); S(1)-C(11), 1.832(9); S(2)-C(13), 1.828(7); C(1)-O(1), 1.150(5); $\mathrm{S}(1)-\mathrm{Ru}(1)-\mathrm{S}(2), 75.40(5) ; \mathrm{Ru}(1)-\mathrm{S}(1)-\mathrm{Ru}(1 \mathrm{~A}), 99.60(6) ; \mathrm{Ru}(1)-\mathrm{S}(2)-\mathrm{Ru}(1 \mathrm{~A}), 100.63(6) ; \mathrm{Ru}(1)-\mathrm{C}(1)-\mathrm{O}(1), 172.1(4)$.

trans geometry such as $\mathbf{9}$ or $\mathbf{1 2}$. However, the strain can be relieved more or less in a cis geometry such as $\mathbf{1 0}$, $\mathbf{1 4}$, or $\mathbf{1 5}$ by twisting two line segments toward the carbonyl side. This twisting also shifts four atoms of $\mathrm{Ru}_{2} \mathrm{SX}$ in $\mathbf{1 4}$ or $\mathrm{Ru}_{2} \mathrm{~S}_{2}$ in $\mathbf{1 0}$ and $\mathbf{1 5}$ away from coplanarity (Scheme 2). The strain relieving is probably effective, and there are five-versus-two cis reaction products favorably formed from 1 and 2 Chart 1 . By comparison of the structure models for $\mathbf{1 5}$ and a hypothetical one, $\mathbf{1 5}^{\prime}$, with ${ }^{i} \mathrm{Pr}$ and ${ }^{t} \mathrm{Bu}$ positions interchanged, there is non-bonding repulsive interaction between the lone pair electrons of the $\mathrm{S}$ atom of ${ }^{i} \operatorname{PrS}$ and a methyl group of ${ }^{t} \mathrm{BuS}$.

\subsection{Reaction of (cis)-[Tp $\left.\mathrm{Ru}_{2}(\mathrm{CO})_{2}(\mu-I)\left(\mu-\mathrm{S}^{i} \mathrm{Pr}\right)\right]$ (11) with $\mathrm{Me}_{3} \mathrm{NO}$}

Following a recent focus of research on the forma- tion of a transition-metal sulfenate $(\mathrm{MS}(=\mathrm{O}) \mathrm{R})$ [10], oxygenation of $(c i s)-\left[\mathrm{Tp}_{2} \mathrm{Ru}_{2}(\mathrm{CO})_{2}(\mu-\mathrm{I})\left(\mu-\mathrm{S}^{i} \mathrm{Pr}\right)\right]$ (11) with trimethylamine oxide was also carried out. Two new carbonyl stretching bands at 1979s and $1945 \mathrm{~m}$ $\mathrm{cm}^{-1}$ and one strong band at $943 \mathrm{~cm}^{-1}$, assigned to $v(\mathrm{~S}=\mathrm{O})$, appeared almost immediately as shown in an IR spectrum measured in $\mathrm{CH}_{2} \mathrm{Cl}_{2}$. The ruthenium sulfenate, $(c i s)-\left[\mathrm{Tp}_{2} \mathrm{Ru}_{2}(\mathrm{CO})_{2}(\mu-\mathrm{I})\left(\mu-\mathrm{S}(\mathrm{O})^{i} \mathrm{Pr}\right)\right]$ (16) was obtained as the only product, which is the first diruthenium sulfenate, to the best of our knowledge [11]. The asymmetric unit of the single crystal used contains two molecules, 16A and 16B, for 16. Both structures are similar to each other, and only structure 16A is shown in Fig. 7. The molecular structure confirms that the mono-oxygenation process is probably stereo- and chemospecific to give the product with an $\mathrm{S}=\mathrm{O}$ bond at an endo rather than exo position with respect to carbonyls (Scheme 3). The $\mathrm{S}-\mathrm{O}$ distances of 
1.509(6) $\AA$ in 16A and 1.534(6) $\AA$ in 16B are similar to that of 1.548(8) $\AA$ in a nickel sulfenate complex [10a].

\section{Experimental}

All solvents were dried and purified by standard methods and were freshly distilled under $\mathrm{N}_{2}$ immediately before use. All reactions and manipulations were carried out in standard Schlenk ware, connected to a switchable double manifold providing vacuum and $\mathrm{N}_{2}$.
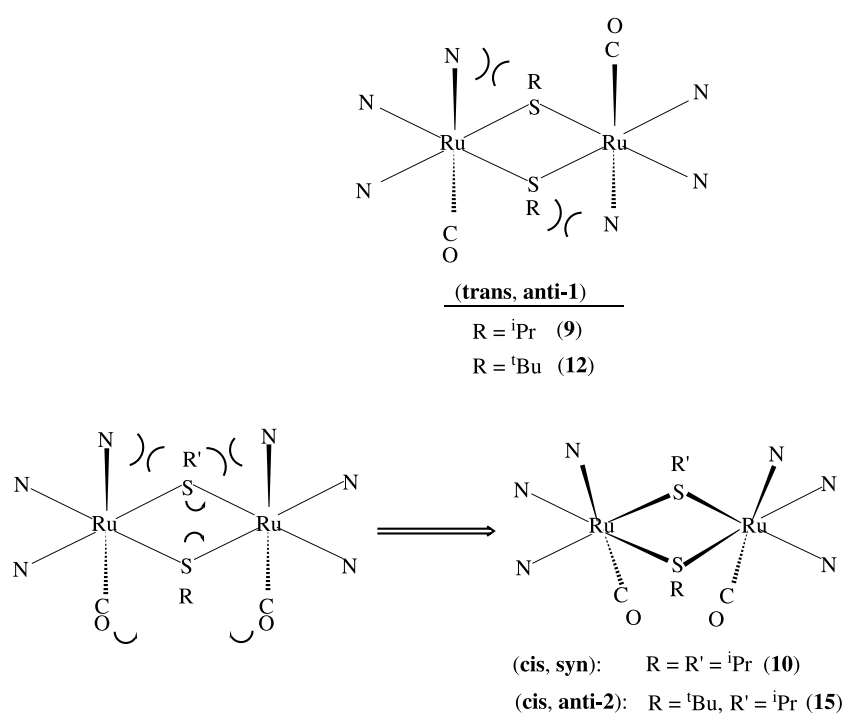

Scheme 2.

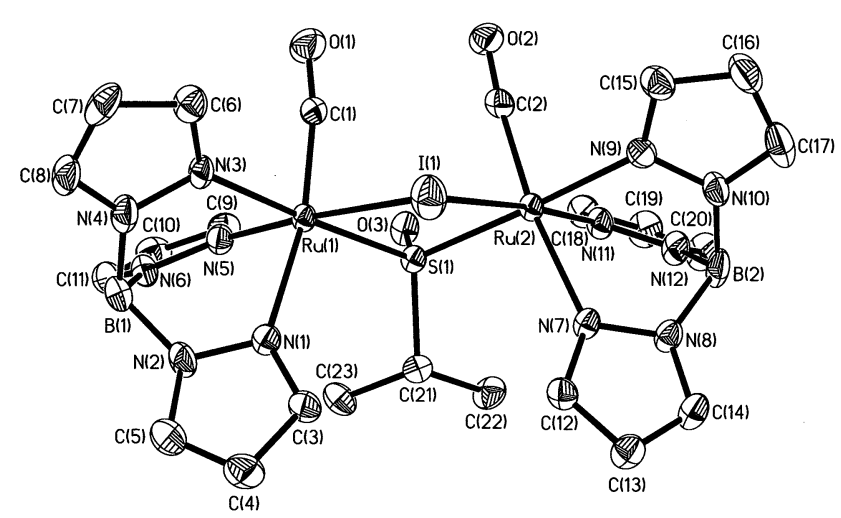

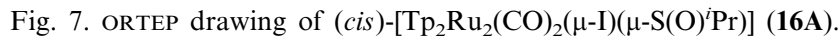
Thermal ellipsoids are drawn at the $30 \%$ probability level. Hydrogen atoms are omitted for clarity. Selected bond distances $(\AA)$ and angles $\left(^{\circ}\right)$ are as follows: $\mathrm{Ru}(1)-\mathrm{C}(1), 1.840(10) ; \mathrm{Ru}(1)-\mathrm{N}(1), 2.171(8)$; $\mathrm{Ru}(1)-\mathrm{N}(3), 2.129(8) ; \mathrm{Ru}(1)-\mathrm{N}(5), 2.066(8) ; \mathrm{Ru}(1)-\mathrm{S}(1), 2.347(2)$; $\mathrm{Ru}(1)-\mathrm{I}(1), 2.7054(12) ; \mathrm{S}(1)-\mathrm{C}(21), 1.828(10) ; \mathrm{C}(1)-\mathrm{O}(1), 1.137(12)$; $\mathrm{Ru}(2)-\mathrm{C}(2), 1.840(10) ; \mathrm{Ru}(2)-\mathrm{N}(7), 2.163(8) ; \mathrm{Ru}(2)-\mathrm{N}(9), 2.142(8)$; $\mathrm{Ru}(2)-\mathrm{N}(11), 2.085(8) ; \mathrm{Ru}(2)-\mathrm{S}(1), 2.344(2) ; \mathrm{Ru}(2)-\mathrm{I}(1), 2.7082(11) ;$ $\mathrm{S}(2)-\mathrm{C}(44), \quad 1.817(10) ; \quad \mathrm{C}(2)-\mathrm{O}(2), \quad 1.139(12) ; \mathrm{S}(1)-\mathrm{O}(3), 1.509(6)$; $\mathrm{O}(3)-\mathrm{S}(1)-\mathrm{C}(21), \quad 104.1(4) ; \quad \mathrm{S}(1)-\mathrm{Ru}(1)-\mathrm{I}(1), \quad 82.35(6) ; \quad \mathrm{Ru}(1)$ $\mathrm{S}(1)-\mathrm{Ru}(2), 104.18(9) ; \mathrm{S}(1)-\mathrm{Ru}(2)-\mathrm{I}(1), 82.33(6) ; \mathrm{Ru}(2)-\mathrm{I}(1)-\mathrm{Ru}(1)$, 86.26(3); $\mathrm{Ru}(1)-\mathrm{C}(1)-\mathrm{O}(1), 170.0(9) ; \mathrm{Ru}(2)-\mathrm{C}(2)-\mathrm{O}(2), 174.8(9)$.
The compound $\left[\mathrm{TpRu}(\mathrm{CO})_{2} \mathrm{X}\right](\mathrm{X}=\mathrm{Br}$, I) was prepared by the literature method [3d]. Reagents were used as supplied by Aldrich, Fluka, or Strem. ${ }^{1} \mathrm{H}$ - and ${ }^{31} \mathrm{P}-\mathrm{NMR}$ spectra were measured on a Brueker AMC$400\left({ }^{1} \mathrm{H}, 400 \mathrm{MHz} ;{ }^{31} \mathrm{P}, 162 \mathrm{MHz}\right) \mathrm{NMR}$ spectrometer. ${ }^{1} \mathrm{H}$ chemical shifts ( $\delta$ in ppm, $J$ in $\mathrm{Hz}$ ) are defined as positive downfield relative to internal $\mathrm{Me}_{4} \mathrm{Si}$ (TMS) or the deuterated solvent, while ${ }^{31} \mathrm{P}$ chemical shifts are referred to external $85 \% \mathrm{H}_{3} \mathrm{PO}_{4}$. The IR spectra were recorded on a BioRad FTS 175 instrument. The following abbreviations were used: s, strong (IR); m, medium; w, weak; s, singlet (NMR); d, doublet; br, broad; m, multiplet. Microanalyses were carried out by the staff of the Microanalytical Service of the Department of Chemistry, National Cheng Kung University.

\subsection{Synthesis of $[T p R u(C O)(N C M e) X](X=B r(\mathbf{1}), I$ (2))}

A solution of complex $\left[\mathrm{TpRu}(\mathrm{CO})_{2} \mathrm{X}\right](1.90 \mathrm{mmol})$ in $\mathrm{MeCN}$ (45 ml) was added dropwise with the $\mathrm{Me}_{3} \mathrm{NO}$ solution, prepared from $0.245 \mathrm{~g}$ of $\mathrm{Me}_{3} \mathrm{NO} \cdot 2 \mathrm{H}_{2} \mathrm{O}(2.21$ $\mathrm{mmol}$ ) in $30 \mathrm{ml}$ of $\mathrm{MeCN}$. The solution was stirred at room temperature (r.t.) for $10 \mathrm{~min}$, and the solvent was removed under vacuum. Recrystallization from $\mathrm{CH}_{2} \mathrm{Cl}_{2}-\mathrm{MeOH}$ gave pure product. [TpRu(CO)(NCMe)Br] (1): yellow; yield 87\%. Anal. Calc. for $\mathrm{C}_{12} \mathrm{H}_{13} \mathrm{BBrN}_{7} \mathrm{ORu}$ : C, 31.13; H, 2.83; N, 21.17. Found: C, 31.09; H, 2.87; N, 21.13\%. ${ }^{1} \mathrm{H}-\mathrm{NMR}\left(\mathrm{CDCl}_{3}\right): \delta 2.33$ $(\mathrm{s}, 3 \mathrm{H}), 6.15\left(\mathrm{t}, 1 \mathrm{H},{ }^{3} J_{\mathrm{H}, \mathrm{H}}=2.2\right), 6.22\left(\mathrm{t}, 1 \mathrm{H},{ }^{3} J_{\mathrm{H}, \mathrm{H}}=\right.$ $2.1), 6.33\left(\mathrm{t}, 1 \mathrm{H},{ }^{3} J_{\mathrm{H}, \mathrm{H}}=2.0\right), 7.53\left(\mathrm{~d}, 1 \mathrm{H},{ }^{3} J_{\mathrm{H}, \mathrm{H}}=2.0\right)$, $7.61\left(\mathrm{~d}, 1 \mathrm{H},{ }^{3} J_{\mathrm{H}, \mathrm{H}}=2.4\right), 7.69\left(\mathrm{~d}, 1 \mathrm{H},{ }^{3} J_{\mathrm{H}, \mathrm{H}}=2.4\right), 7.73$ $\left(\mathrm{d}, 1 \mathrm{H},{ }^{3} J_{\mathrm{H}, \mathrm{H}}=2.4\right), 7.80\left(\mathrm{~d}, 1 \mathrm{H},{ }^{3} J_{\mathrm{H}, \mathrm{H}}=2.0\right), 8.16(\mathrm{~d}$, $\left.1 \mathrm{H},{ }^{3} J_{\mathrm{H}, \mathrm{H}}=2.0\right)$. IR $\left(\mathrm{CH}_{2} \mathrm{Cl}_{2}\right): v_{\mathrm{B}-\mathrm{H}}, 2495 \mathrm{w} ; v_{\mathrm{CO}}, 1981 \mathrm{~s}$ $\mathrm{cm}^{-1}$. [TpRu(CO)(NCMe)I] (2): yellow; yield $84 \%$. Anal. Calc. for $\mathrm{C}_{12} \mathrm{H}_{13} \mathrm{BIN}_{7} \mathrm{ORu}$ : C, 28.26; $\mathrm{H}, 2.57$; N, 19.22. Found: C, 28.03; H, 2.54; N, 18.95\%. ${ }^{1} \mathrm{H}-\mathrm{NMR}$ $\left(\mathrm{CDCl}_{3}\right): \delta 2.40(\mathrm{~s}, 3 \mathrm{H}), 6.13\left(\mathrm{t}, 1 \mathrm{H},{ }^{3} J_{\mathrm{H}, \mathrm{H}}=2.8\right), 6.23$ $\left(\mathrm{t}, 1 \mathrm{H},{ }^{3} J_{\mathrm{H}, \mathrm{H}}=2.8\right), 6.32\left(\mathrm{t}, 1 \mathrm{H},{ }^{3} J_{\mathrm{H}, \mathrm{H}}=2.8\right), 7.54(\mathrm{~d}$, $\left.1 \mathrm{H},{ }^{3} J_{\mathrm{H}, \mathrm{H}}=2.4\right), 7.60\left(\mathrm{~d}, 1 \mathrm{H},{ }^{3} J_{\mathrm{H}, \mathrm{H}}=2.4\right), 7.67(\mathrm{~d}, 1 \mathrm{H}$, $\left.{ }^{3} J_{\mathrm{H}, \mathrm{H}}=2.4\right), 7.70\left(\mathrm{~d}, 1 \mathrm{H},{ }^{3} J_{\mathrm{H}, \mathrm{H}}=2.4\right), 7.89(\mathrm{~d}, 1 \mathrm{H}$, $\left.{ }^{3} J_{\mathrm{H}, \mathrm{H}}=2.4\right), 8.28\left(\mathrm{~d}, 1 \mathrm{H},{ }^{3} J_{\mathrm{H}, \mathrm{H}}=2.4\right)$. IR $\left(\mathrm{CH}_{2} \mathrm{Cl}_{2}\right)$ : $v_{\mathrm{B}-\mathrm{H}}, 2495 \mathrm{w} ; v_{\mathrm{CO}}, 1979 \mathrm{~s} \mathrm{~cm}^{-1}$.

\subsection{Synthesis of $[\mathrm{TpRu}(\mathrm{CO})(\mathrm{CNR}) \mathrm{Br}]\left(\mathrm{R}=\mathrm{PhCH}_{2}\right.$ (3), ${ }^{t} \mathrm{Bu}$ (4)) and $[\mathrm{TpRu}(\mathrm{CO})(\mathrm{CNR}) \mathrm{I}]\left(\mathrm{R}=\mathrm{PhCH}_{2}\right.$ (5), $\left.{ }^{t} \mathrm{Bu}(\mathbf{6})\right)$}

These yellow compounds were prepared by using a similar procedure described below for the synthesis of compound 6. tert-Butylisocyanide $(0.093 \mathrm{~g}, 1.10 \mathrm{mmol})$ was added to a stirred solution of $2(0.510 \mathrm{~g}, 1.00$ $\mathrm{mmol}$ ) in $30 \mathrm{ml}$ of THF. The solution was then heated under reflux for $12 \mathrm{~h}$. The volatiles were stripped off under vacuum. Recrystallization from $\mathrm{CH}_{2} \mathrm{Cl}_{2}-\mathrm{MeOH}$ gave $0.362 \mathrm{~g}$ of 6 . Yield $66 \%$. [TpRu(CO) $\left(\mathrm{CNCH}_{2} \mathrm{Ph}\right)-$ 


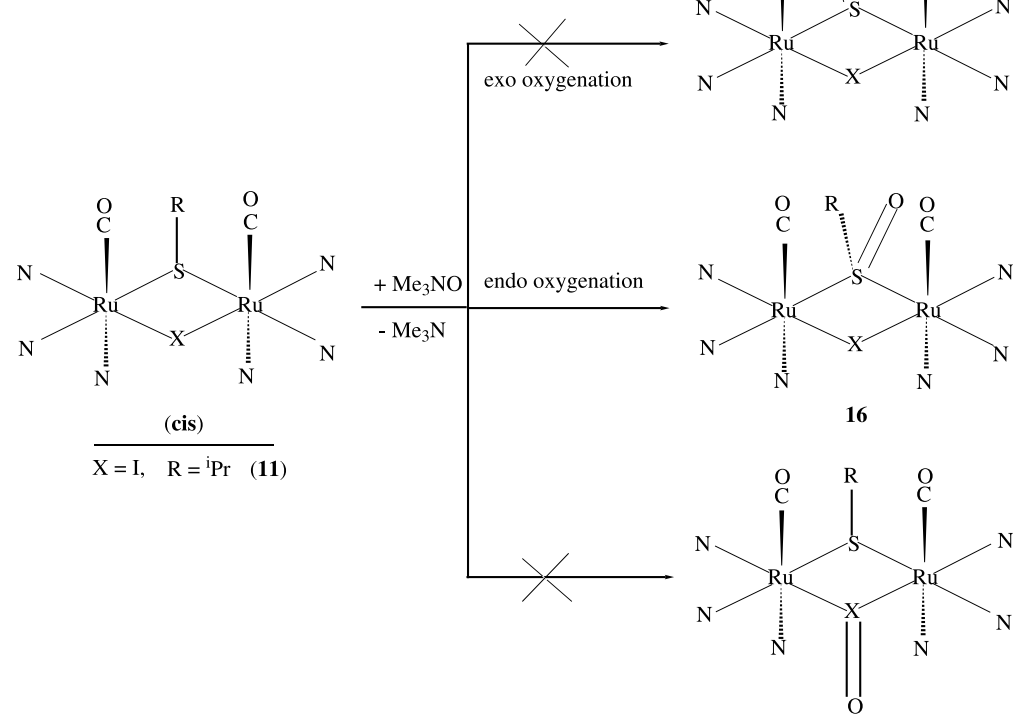

Scheme 3.

Br] (3): Anal. Calc. for $\mathrm{C}_{18} \mathrm{H}_{17} \mathrm{BBrN}_{7} \mathrm{ORu}$ : C, 40.10; $\mathrm{H}$, 3.18; N, 18.19. Found: C, 39.70; H, 3.22; N, 17.88\%. ${ }^{1} \mathrm{H}-\mathrm{NMR}\left(\mathrm{CD}_{2} \mathrm{Cl}_{2}\right): \delta 5.07(\mathrm{~s}, 2 \mathrm{H}), 6.20\left(\mathrm{t}, 1 \mathrm{H},{ }^{3} J_{\mathrm{H}, \mathrm{H}}=\right.$ 2.3), $6.27(\mathrm{~m}, 2 \mathrm{H}), 7.33(\mathrm{~m}, 6 \mathrm{H}), 7.71(\mathrm{~m}, 3 \mathrm{H}), 7.95(\mathrm{~m}$, 2H). IR $\left(\mathrm{CH}_{2} \mathrm{Cl}_{2}\right): v_{\mathrm{B}-\mathrm{H}}, 2493 ; v_{\mathrm{CN}}, 2184 ; v_{\mathrm{CO}}, 1995 \mathrm{~s}$ $\mathrm{cm}^{-1}$. [TpRu(CO) $\left.\left(\mathrm{CN}^{t} \mathrm{Bu}\right) \mathrm{Br}\right]$ (4): Anal. Calc. for $\mathrm{C}_{15} \mathrm{H}_{19} \mathrm{BBrN}_{7} \mathrm{ORu}: \mathrm{C}, 35.67 ; \mathrm{H}, 3.79 ; \mathrm{N}, 19.41$. Found: C, 35.58; H, 3.85; N, 19.28\%. ${ }^{1} \mathrm{H}-\mathrm{NMR}\left(\mathrm{CDCl}_{3}\right): \delta 1.53$ (s, 9H), $6.21(\mathrm{br}, 1 \mathrm{H}), 6.26(\mathrm{br}, 1 \mathrm{H}), 6.30(\mathrm{br}, 1 \mathrm{H}), 7.48$ (br, 1H), $7.70(\mathrm{~m}, 3 \mathrm{H}), 7.92(\mathrm{br}, 1 \mathrm{H}), 7.98$ (br, 1H). IR $\left(\mathrm{CH}_{2} \mathrm{Cl}_{2}\right): v, 2495 ; v_{\mathrm{CN}}, 2172 \mathrm{~s} ; v_{\mathrm{CO}}, 1991 \mathrm{~s} \mathrm{~cm}^{-1}$. [TpRu(CO) $\left.\left(\mathrm{CNCH}_{2} \mathrm{Ph}\right) \mathrm{I}\right]$ (5): Anal. Calc. for $\mathrm{C}_{18} \mathrm{H}_{17} \mathrm{BIN}_{7^{-}}$ ORu: C, 36.88; H, 2.92; N, 16.73. Found: C, 36.81; H, 2.95; N, 16.67\%. ${ }^{1} \mathrm{H}-\mathrm{NMR}\left(\mathrm{C}_{3} \mathrm{H}_{6} \mathrm{O}-d_{6}\right): \delta 5.33(\mathrm{~s}, 2 \mathrm{H})$, $6.27\left(\mathrm{t}, 1 \mathrm{H},{ }^{3} J_{\mathrm{H}, \mathrm{H}}=2.2\right), 6.30(\mathrm{~m}, 2 \mathrm{H}), 7.37(\mathrm{~m}, 3 \mathrm{H})$, $7.55(\mathrm{~m}, 2 \mathrm{H}), 7.76\left(\mathrm{~d}, 1 \mathrm{H},{ }^{3} J_{\mathrm{H}, \mathrm{H}}=1.8\right), 7.85(\mathrm{br}, 3 \mathrm{H})$, $7.89\left(\mathrm{~d}, 1 \mathrm{H},{ }^{3} J_{\mathrm{H}, \mathrm{H}}=2.4\right), 8.04\left(\mathrm{~d}, 1 \mathrm{H},{ }^{3} J_{\mathrm{H}, \mathrm{H}}=1.8\right), 8.07$ $\left(\mathrm{d}, 1 \mathrm{H},{ }^{3} J_{\mathrm{H}, \mathrm{H}}=1.8\right)$. IR $\left(\mathrm{CH}_{2} \mathrm{Cl}_{2}\right): v_{\mathrm{B}-\mathrm{H}}, 2492 \mathrm{w} ; v_{\mathrm{CN}}$, 2182s; $v_{\mathrm{CO}}, 1993 \mathrm{~s} \mathrm{~cm}{ }^{-1}$. [TpRu(CO) $\left.\left(\mathrm{CN}^{t} \mathrm{Bu}\right) \mathrm{I}\right]$ (6): Anal. Calc. for $\mathrm{C}_{15} \mathrm{H}_{19} \mathrm{BIN}_{7} \mathrm{ORu}$ : C, 32.63; H, 3.47; N, 17.76. Found: C, 32.26; H, 3.45; N, $17.57 \%$. ${ }^{1} \mathrm{H}-\mathrm{NMR}$ $\left(\mathrm{C}_{3} \mathrm{H}_{6} \mathrm{O}-d_{6}\right): \delta 1.55(\mathrm{~s}, 2 \mathrm{H}), 6.28\left(\mathrm{t}, 1 \mathrm{H},{ }^{3} J_{\mathrm{H}, \mathrm{H}}=2.2\right)$, $6.29\left(\mathrm{t}, 1 \mathrm{H},{ }^{3} J_{\mathrm{H}, \mathrm{H}}=2.2\right), 6.31\left(\mathrm{t}, 1 \mathrm{H},{ }^{3} J_{\mathrm{H}, \mathrm{H}}=2.2\right), 7.76$ $\left(\mathrm{d}, 1 \mathrm{H},{ }^{3} J_{\mathrm{H}, \mathrm{H}}=1.6\right), 7.84\left(\mathrm{~d}, 1 \mathrm{H},{ }^{3} J_{\mathrm{H}, \mathrm{H}}=2.4\right), 7.85(\mathrm{~d}$, $\left.1 \mathrm{H},{ }^{3} J_{\mathrm{H}, \mathrm{H}}=2.4\right), 7.88\left(\mathrm{~d}, 1 \mathrm{H},{ }^{3} J_{\mathrm{H}, \mathrm{H}}=2.0\right), 8.02(\mathrm{~d}, 1 \mathrm{H}$, $\left.{ }^{3} J_{\mathrm{H}, \mathrm{H}}=1.6\right), 8.12\left(\mathrm{~d}, 1 \mathrm{H},{ }^{3} J_{\mathrm{H}, \mathrm{H}}=2.0\right)$. IR $\left(\mathrm{CH}_{2} \mathrm{Cl}_{2}\right)$ : $v_{\mathrm{B}-\mathrm{H}}, 2493 \mathrm{w} ; v_{\mathrm{CN}}, 2168 \mathrm{~s} ; v_{\mathrm{CO}}, 1989 \mathrm{~s} \mathrm{~cm}^{-1}$.

\subsection{Preparation of $\left[T p R u(C O)\left(\eta^{2}-S_{2} C N R_{2}\right)\right]\left(R^{\prime}=M e\right.$ (7), Et (8))}

Compound $\mathbf{7}$ and $\mathbf{8}$ were prepared similarly by using the procedure described below for the synthesis of the yellow-green compound 7. $\mathrm{Na}^{+} \mathrm{S}_{2} \mathrm{CNMe}_{2}^{-}(0.082 \mathrm{~g}$, $0.573 \mathrm{mmol})$ was added to a stirred solution of $2(0.240$ $\mathrm{g}, 0.481 \mathrm{mmol})$ in $30 \mathrm{ml}$ of $\mathrm{MeOH}$. The solution was then heated under reflux for $14 \mathrm{~h}$. The volatiles were stripped off under vacuum. Recrystallization from $\mathrm{CH}_{2} \mathrm{Cl}_{2}-\mathrm{MeOH}$ gave 0.171 g. Yield $79 \%$. $\left[\mathrm{TpRu}(\mathrm{CO})\left(\eta^{2}-\mathrm{S}_{2} \mathrm{CNMe}_{2}\right)\right]$ (7): yellow-green. Anal. Calc. for $\mathrm{C}_{13} \mathrm{H}_{16} \mathrm{BN}_{7} \mathrm{ORuS}_{2}$ : C, 33.77; $\mathrm{H}, 3.48 ; \mathrm{N}$, 21.20. Found: C, 33.69; H, 3.45; N, 21.04\%. ${ }^{1} \mathrm{H}-\mathrm{NMR}$ $\left(\mathrm{C}_{3} \mathrm{H}_{6} \mathrm{O}-d_{6}\right): \delta 3.36(\mathrm{~s}, 6 \mathrm{H}), 6.25\left(\mathrm{t}, 2 \mathrm{H},{ }^{3} J_{\mathrm{H}, \mathrm{H}}=2.2\right)$, $6.29\left(\mathrm{t}, 1 \mathrm{H},{ }^{3} J_{\mathrm{H}, \mathrm{H}}=2.1\right), 7.63\left(\mathrm{~d}, 2 \mathrm{H},{ }^{3} J_{\mathrm{H}, \mathrm{H}}=2.1\right), 7.88$ (m, 4H). IR $\left(\mathrm{CH}_{2} \mathrm{Cl}_{2}\right): v_{\mathrm{B}-\mathrm{H}}, 2487 \mathrm{w} ; v_{\mathrm{CO}}, 1949 \mathrm{~s} ; v_{\mathrm{CN}}$, $1501 \mathrm{~s} \mathrm{~cm}^{-1}$. [TpRu(CO) $\left.\left(\eta^{2}-\mathrm{S}_{2} \mathrm{CNEt}_{2}\right)\right](\mathbf{8})$ : pale green, yield $79 \%$. Anal. Calc. for $\mathrm{C}_{15} \mathrm{H}_{20} \mathrm{BN}_{7} \mathrm{ORuS}_{2}$ : C, 36.74; H, 4.11; N, 19.99. Found: C, 36.63; H, 4.03; N, 19.88\%. ${ }^{1} \mathrm{H}-\mathrm{NMR}\left(\mathrm{C}_{3} \mathrm{H}_{6} \mathrm{O}-d_{6}\right): \delta 1.33\left(\mathrm{t}, 6 \mathrm{H},{ }^{3} J_{\mathrm{H}, \mathrm{H}}=7.2\right), 3.84$ $(\mathrm{m}, 4 \mathrm{H}), 6.25\left(\mathrm{t}, 2 \mathrm{H},{ }^{3} J_{\mathrm{H}, \mathrm{H}}=2.1\right), 6.31\left(\mathrm{t}, 2 \mathrm{H},{ }^{3} J_{\mathrm{H}, \mathrm{H}}=\right.$ 2.1), $7.62\left(\mathrm{~d}, 2 \mathrm{H},{ }^{3} J_{\mathrm{H}, \mathrm{H}}=2.0\right), 7.88(\mathrm{~m}, 4 \mathrm{H})$. IR $\left(\mathrm{CH}_{2} \mathrm{Cl}_{2}\right): v_{\mathrm{B}-\mathrm{H}}, 2489 \mathrm{w} ; v_{\mathrm{CO}}, 1947 \mathrm{~s} ; v_{\mathrm{CN}}, 1501 \mathrm{~s} \mathrm{~cm}^{-1}$.

\subsection{Reaction of $[T p R u(C O)(N C M e) B r]$ (1) with ${ }^{i} \mathrm{PrSH}$ and $\mathrm{Et}_{3} \mathrm{~N}$}

Compound 1 (0.293 g, $0.63 \mathrm{mmol}),{ }^{i} \mathrm{PrSH}$ (ca. $0.5 \mathrm{ml}$, $5.22 \mathrm{mmol}$ ), $\mathrm{Et}_{3} \mathrm{~N}$ (ca. $0.5 \mathrm{ml}, 3.59 \mathrm{mmol}$ ) and 1,2dimethoxyethane $(20 \mathrm{ml})$ were heated under reflux for $20 \mathrm{~h}$. The solvent and volatiles were then removed under vacuum, and the residue was taken up in a minimum amount of $\mathrm{CH}_{2} \mathrm{Cl}_{2}$. The products were separated by thin-layer chromatography using $\mathrm{CH}_{2} \mathrm{Cl}_{2}-$ $\mathrm{C}_{6} \mathrm{H}_{14}$ mixed solvents to give $2.6 \mathrm{mg}$ of (trans, anti-1)-[Tp $\left.\mathrm{Tu}_{2}(\mathrm{CO})_{2}\left(\mu-\mathrm{S}^{i} \mathrm{Pr}\right)_{2}\right]$ (9) $(0.5 \%)$ and $109 \mathrm{mg}$ of (cis, syn)-[Tp $\left.\mathrm{Tp}_{2} \mathrm{Ru}_{2}(\mathrm{CO})_{2}\left(\mu-\mathrm{S}^{i} \mathrm{Pr}\right)_{2}\right](\mathbf{1 0})(20.7 \%)$. (trans, 
anti-1)-[Tp $\left.\mathrm{T}_{2} \mathrm{Ru}_{2}(\mathrm{CO})_{2}\left(\mu-\mathrm{S}^{i} \mathrm{Pr}\right)_{2}\right]$ (9): yellow. Anal. Calc. for $\mathrm{C}_{26} \mathrm{H}_{34} \mathrm{~B}_{2} \mathrm{~N}_{12} \mathrm{O}_{2} \mathrm{RU}_{2} \mathrm{~S}_{2}$ : C, 37.42; H, 4.11; N, 20.14 . Found: C, 37.24; H, 3.93; N, 20.02\%. ${ }^{1} \mathrm{H}-\mathrm{NMR}$ $\left(\mathrm{CDCl}_{3}\right): \delta 1.51\left(\mathrm{~d}, 12 \mathrm{H},{ }^{3} J_{\mathrm{H}, \mathrm{H}}=6.8\right), 4.20(\mathrm{~m}, 2 \mathrm{H})$, $6.17(\mathrm{t}, 2 \mathrm{H}), 6.18(\mathrm{t}, 2 \mathrm{H}), 6.29(\mathrm{t}, 2 \mathrm{H}), 7.59(\mathrm{~d}, 2 \mathrm{H}$, $\left.{ }^{3} J_{\mathrm{H}, \mathrm{H}}=2.0\right), 7.60\left(\mathrm{~d}, 2 \mathrm{H},{ }^{3} J_{\mathrm{H}, \mathrm{H}}=2.0\right), 7.66(\mathrm{~d}, 2 \mathrm{H}$, $\left.{ }^{3} J_{\mathrm{H}, \mathrm{H}}=2.0\right), 7.67\left(\mathrm{~d}, 2 \mathrm{H},{ }^{3} J_{\mathrm{H}, \mathrm{H}}=2.0\right), 7.73(\mathrm{~d}, 2 \mathrm{H}$, $\left.{ }^{3} J_{\mathrm{H}, \mathrm{H}}=2.0\right), 7.79\left(\mathrm{~d}, 2 \mathrm{H},{ }^{3} J_{\mathrm{H}, \mathrm{H}}=2.0\right)$. IR $\left(\mathrm{CH}_{2} \mathrm{Cl}_{2}\right)$ : $v_{\mathrm{B}-\mathrm{H}}, \quad 2491 \mathrm{w} ; \quad v_{\mathrm{CO}}, \quad 1962 \mathrm{~s} \quad \mathrm{~cm}^{-1}$. (cis, syn)$\left[\mathrm{Tp}_{2} \mathrm{Ru}_{2}(\mathrm{CO})_{2}\left(\mu-\mathrm{S}^{i} \mathrm{Pr}\right)_{2}\right] \quad(\mathbf{1 0})$ : orange-yellow. Anal. Calc. for $\mathrm{C}_{26} \mathrm{H}_{34} \mathrm{~B}_{2} \mathrm{~N}_{12} \mathrm{O}_{2} \mathrm{Ru}_{2} \mathrm{~S}_{2}: \mathrm{C}, 37.42 ; \mathrm{H}, 4.11 ; \mathrm{N}$, 20.14. Found: C, 37.14; H, 4.08; N, 20.07\%. ${ }^{1} \mathrm{H}-\mathrm{NMR}$ $\left(\mathrm{CDCl}_{3}\right): \delta 0.50\left(\mathrm{~d}, 12 \mathrm{H},{ }^{3} J_{\mathrm{H}, \mathrm{H}}=6.8\right), 2.70(\mathrm{~m}, 2 \mathrm{H})$, $6.18(\mathrm{t}, 4 \mathrm{H}), 6.45(\mathrm{t}, 2 \mathrm{H}), 7.61\left(\mathrm{~d}, 4 \mathrm{H},{ }^{3} J_{\mathrm{H}, \mathrm{H}}=2.4\right), 7.82$ $\left(\mathrm{d}, 2 \mathrm{H},{ }^{3} J_{\mathrm{H}, \mathrm{H}}=2.0\right), 7.88\left(\mathrm{~d}, 2 \mathrm{H},{ }^{3} J_{\mathrm{H}, \mathrm{H}}=2.4\right), 8.92(\mathrm{~d}$, $\left.2 \mathrm{H},{ }^{3} J_{\mathrm{H}, \mathrm{H}}=2.0\right)$. IR: $v_{\mathrm{B}-\mathrm{H}}, 2487 \mathrm{w} ; v_{\mathrm{CO}}, 1981 \mathrm{sh}, 1968 \mathrm{~s}$ $\mathrm{cm}^{-1}$ in $\mathrm{CH}_{2} \mathrm{Cl}_{2}$ and $v_{\mathrm{B}-\mathrm{H}}, 2477 \mathrm{w} ; v_{\mathrm{CO}}, 1989 \mathrm{~m}, 1979 \mathrm{~s}$ $\mathrm{cm}^{-1}$ in $\mathrm{C}_{6} \mathrm{H}_{14}$.

\subsection{Reaction of $[\mathrm{TpRu}(\mathrm{CO})(\mathrm{NCMe}) \mathrm{I}]$ (2) with ${ }^{i} \mathrm{PrSH}$ and $E t_{3} N$}

Compound 2 ( $0.301 \mathrm{~g}, 0.59 \mathrm{mmol}),{ }^{i} \mathrm{PrSH}$ (ca. $0.5 \mathrm{ml}$, $5.22 \mathrm{mmol}$ ), $\mathrm{Et}_{3} \mathrm{~N}$ (ca. $0.5 \mathrm{ml}, 3.59 \mathrm{mmol}$ ) and 1,2dimethoxyethane $(20 \mathrm{ml})$ were heated under reflux for 2 $\mathrm{h}$. The solvent and volatiles were then removed under vacuum, and the residue was taken up in a minimum amount of $\mathrm{CH}_{2} \mathrm{Cl}_{2}$. The products were separated by thin-layer chromatography using $\mathrm{CH}_{2} \mathrm{Cl}_{2}-\mathrm{C}_{6} \mathrm{H}_{14}$ mixed solvents to give $9.3 \mathrm{mg}$ of (trans, anti-1)$\left[\mathrm{Tp}_{2} \mathrm{Ru}_{2}(\mathrm{CO})_{2}\left(\mu-\mathrm{S}^{i} \mathrm{Pr}\right)_{2}\right](9)(1.9 \%), 53.4 \mathrm{mg}$ of (cis, syn)$\left[\mathrm{Tp}_{2} \mathrm{Ru}_{2}(\mathrm{CO})_{2}(\mu-\mathrm{S} \mathrm{Pr})_{2}\right]$ (10) $(10.8 \%)$, and $3.2 \mathrm{mg}$ of $($ cis $)-\left[\mathrm{Tp}_{2} \mathrm{Ru}_{2}(\mathrm{CO})_{2}(\mu-\mathrm{I})\left(\mu-\mathrm{S}^{i} \mathrm{Pr}\right)\right] \quad$ (11) $\quad(0.7 \%) . \quad$ (cis)$\left[\mathrm{Tp}_{2} \mathrm{Ru}_{2}(\mathrm{CO})_{2}(\mu-\mathrm{I})\left(\mu-\mathrm{S}{ }^{i} \mathrm{Pr}\right)\right]$ (11): yellow-brown. Anal. Calc. for $\mathrm{C}_{23} \mathrm{H}_{27} \mathrm{~B}_{2} \mathrm{IN}_{12} \mathrm{O}_{2} \mathrm{Ru}_{2} \mathrm{~S}: \mathrm{C}, 31.17 ; \mathrm{H}, 3.07 ; \mathrm{N}$, 18.96. Found: C, 31.02; H, 3.07; N, $18.87 \%$. ${ }^{1} \mathrm{H}-\mathrm{NMR}$ $\left(\mathrm{CDCl}_{3}\right): \delta 0.89\left(\mathrm{~d}, 6 \mathrm{H},{ }^{3} J_{\mathrm{H}, \mathrm{H}}=6.4\right), 2.88(\mathrm{~m}, 1 \mathrm{H}), 6.17$ $(\mathrm{t}, 2 \mathrm{H}), 6.21(\mathrm{t}, 2 \mathrm{H}), 6.44(\mathrm{t}, 2 \mathrm{H}), 7.58\left(\mathrm{~d}, 2 \mathrm{H},{ }^{3} J_{\mathrm{H}, \mathrm{H}}=\right.$ 2.4), $7.67\left(\mathrm{~d}, 2 \mathrm{H},{ }^{3} J_{\mathrm{H}, \mathrm{H}}=2.4\right), 7.74\left(\mathrm{~d}, 2 \mathrm{H},{ }^{3} J_{\mathrm{H}, \mathrm{H}}=2.0\right)$, $7.80\left(\mathrm{~d}, 2 \mathrm{H},{ }^{3} J_{\mathrm{H}, \mathrm{H}}=2.4\right), 7.94\left(\mathrm{~d}, 2 \mathrm{H},{ }^{3} J_{\mathrm{H}, \mathrm{H}}=2.0\right), 8.86$ $\left(\mathrm{d}, 2 \mathrm{H},{ }^{3} J_{\mathrm{H}, \mathrm{H}}=2.0\right)$. IR $\left(\mathrm{CH}_{2} \mathrm{Cl}_{2}\right): v_{\mathrm{B}-\mathrm{H}}, 2489 \mathrm{w} ; v_{\mathrm{CO}}$, $1981 \mathrm{~s}, 1949 \mathrm{~m} \mathrm{~cm}^{-1}$.

\subsection{Reaction of $[\mathrm{TpRu}(\mathrm{CO})(\mathrm{NCMe}) \mathrm{Br}]$ (1) with ${ }^{t} \mathrm{BuSH}$ and $E t_{3} N$}

Compound 1 (0.232 g, $0.50 \mathrm{mmol}),{ }^{t} \mathrm{BuSH}$ (ca. 0.5 $\mathrm{ml}, 4.40 \mathrm{mmol}$ ), $\mathrm{Et}_{3} \mathrm{~N}$ (ca. $0.5 \mathrm{ml}, 3.59 \mathrm{mmol}$ ) and 1,2-dimethoxyethane $(30 \mathrm{ml})$ were heated under reflux for $44 \mathrm{~h}$. The solvent and volatiles were then removed under vacuum, and the residue was taken up in a minimum amount of $\mathrm{CH}_{2} \mathrm{Cl}_{2}$. The products were separated by thin-layer chromatography using $\mathrm{CH}_{2} \mathrm{Cl}_{2}-$ $\mathrm{C}_{6} \mathrm{H}_{14}$ mixed solvents to give $0.3 \mathrm{mg}$ of (trans,

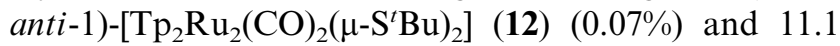
$\mathrm{mg}$ of $($ cis $)-\left[\mathrm{Tp}_{2} \mathrm{Ru}_{2}(\mathrm{CO})_{2}(\mu-\mathrm{Br})\left(\mu-\mathrm{S}^{t} \mathrm{Bu}\right)_{2}\right]$ (13) $(2.6 \%)$.

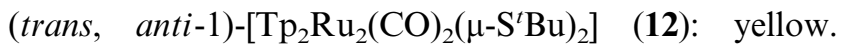
Anal. Calc. for $\mathrm{C}_{28} \mathrm{H}_{38} \mathrm{~B}_{2} \mathrm{~N}_{12} \mathrm{O}_{2} \mathrm{Ru}_{2} \mathrm{~S}_{2}$ : C, 38.99; H, 4.44; $\mathrm{N}, 19.49$. Found: C, 38.84; H, 4.43; N, $19.37 \%$. ${ }^{1} \mathrm{H}-$ NMR $\left(\mathrm{CDCl}_{3}\right): \delta 1.74(\mathrm{~s}, 18 \mathrm{H}), 6.18(\mathrm{~m}, 4 \mathrm{H}), 6.30(\mathrm{t}$, $2 \mathrm{H}), 7.59(\mathrm{~m}, 4 \mathrm{H}), 7.66(\mathrm{~m}, 4 \mathrm{H}), 7.73\left(\mathrm{~d}, 2 \mathrm{H},{ }^{3} J_{\mathrm{H}, \mathrm{H}}=\right.$ 2.4), $7.84\left(\mathrm{~d}, 2 \mathrm{H},{ }^{3} J_{\mathrm{H}, \mathrm{H}}=2.0\right)$. IR $\left(\mathrm{CH}_{2} \mathrm{Cl}_{2}\right): v_{\mathrm{B}-\mathrm{H}}$, $2489 \mathrm{w} ; v_{\mathrm{CO}}, 1964 \mathrm{~s} \mathrm{~cm}^{-1}$. (cis)-[Tp $\mathrm{Tp}_{2} \mathrm{Ru}_{2}(\mathrm{CO})_{2}(\mu-\mathrm{Br})(\mu-$ $\left.\mathrm{S}^{t} \mathrm{Bu}\right)_{2}$ ] (13): orange-yellow. Anal. Calc. for $\mathrm{C}_{24} \mathrm{H}_{29} \mathrm{~B}_{2} \mathrm{BrN}_{12} \mathrm{O}_{2} \mathrm{Ru}_{2} \mathrm{~S}$ : C, 33.78; H, 3.43; N, 19.70 . Found: C, 33.67; H, 3.43; N, 19.62\%. ${ }^{1} \mathrm{H}-\mathrm{NMR}$ $\left(\mathrm{CDCl}_{3}\right): \delta 1.02(\mathrm{~s}, 9 \mathrm{H}), 6.16(\mathrm{t}, 2 \mathrm{H}), 6.18(\mathrm{t}, 2 \mathrm{H}), 6.50$ $(\mathrm{t}, 2 \mathrm{H}), 7.57\left(\mathrm{~d}, 2 \mathrm{H},{ }^{3} J_{\mathrm{H}, \mathrm{H}}=2.4\right), 7.76\left(\mathrm{~d}, 2 \mathrm{H},{ }^{3} J_{\mathrm{H}, \mathrm{H}}=\right.$ 2.4), $7.77\left(\mathrm{~d}, 2 \mathrm{H},{ }^{3} J_{\mathrm{H}, \mathrm{H}}=2.0\right), 7.83\left(\mathrm{~d}, 4 \mathrm{H},{ }^{3} J_{\mathrm{H}, \mathrm{H}}=2.0\right)$, $7.92\left(\mathrm{~d}, 2 \mathrm{H},{ }^{3} J_{\mathrm{H}, \mathrm{H}}=2.0\right), 9.07\left(\mathrm{~d}, 2 \mathrm{H},{ }^{3} J_{\mathrm{H}, \mathrm{H}}=2.0\right)$. IR $\left(\mathrm{CH}_{2} \mathrm{Cl}_{2}\right): v_{\mathrm{B}-\mathrm{H}}, 2489 \mathrm{w} ; v_{\mathrm{CO}}, 1976 \mathrm{~s}, 1935 \mathrm{~m} \mathrm{~cm}^{-1}$.

\subsection{Reaction of $[T p R u(C O)(N C M e) I]$ (2) with ${ }^{t} \mathrm{BuSH}$ and $\mathrm{Et}_{3} \mathrm{~N}$}

Compound 2 (0.311 g, $0.61 \mathrm{mmol}),{ }^{t} \mathrm{BuSH}$ (ca. 0.5 $\mathrm{ml}, 4.40 \mathrm{mmol}$ ), $\mathrm{Et}_{3} \mathrm{~N}$ (ca. $0.5 \mathrm{ml}, 3.59 \mathrm{mmol}$ ) and 1,2-dimethoxyethane $(20 \mathrm{ml})$ were heated under reflux for $16 \mathrm{~h}$. The solvent and volatiles were then removed under vacuum, and the residue was taken up in a minimum amount of $\mathrm{CH}_{2} \mathrm{Cl}_{2}$. The products were separated by thin-layer chromatography using $\mathrm{CH}_{2} \mathrm{Cl}_{2}-$ $\mathrm{C}_{6} \mathrm{H}_{14}$ mixed solvents to give $1.0 \mathrm{mg}$ of (trans, anti-1)-[ $\left.\mathrm{Tp}_{2} \mathrm{Ru}_{2}(\mathrm{CO})_{2}\left(\mu-\mathrm{S}^{t} \mathrm{Bu}\right)_{2}\right](\mathbf{1 2})(0.19 \%)$ and 48.7 $\mathrm{mg}$ of $($ cis $)-\left[\mathrm{Tp}_{2} \mathrm{Ru}_{2}(\mathrm{CO})_{2}(\mu-\mathrm{I})\left(\mu-\mathrm{S}^{t} \mathrm{Bu}\right)_{2}\right]$ (14) (8.9\%). (cis)-[Tp $\left.\mathrm{Ru}_{2}(\mathrm{CO})_{2}(\mu-\mathrm{I})\left(\mu-\mathrm{S}^{t} \mathrm{Bu}\right)_{2}\right]$ (14): yellow-brown. Anal. Calc. for $\mathrm{C}_{24} \mathrm{H}_{29} \mathrm{~B}_{2} \mathrm{IN}_{12} \mathrm{O}_{2} \mathrm{Ru}_{2} \mathrm{~S}$ : C, 32.02; H, 3.25; N, 18.67. Found: C, 31.98; H, 3.23; N, $18.62 \%$. ${ }^{1} \mathrm{H}-$ NMR $\left(\mathrm{CDCl}_{3}\right): \delta 0.88(\mathrm{~s}, 9 \mathrm{H}), 6.13(\mathrm{t}, 2 \mathrm{H}), 6.20(\mathrm{t}$, $2 \mathrm{H}), 6.50(\mathrm{t}, 2 \mathrm{H}), 7.55\left(\mathrm{~d}, 2 \mathrm{H},{ }^{3} J_{\mathrm{H}, \mathrm{H}}=2.4\right), 7.66(\mathrm{~d}, 2 \mathrm{H}$, $\left.{ }^{3} J_{\mathrm{H}, \mathrm{H}}=2.4\right), 7.81\left(\mathrm{~d}, 2 \mathrm{H},{ }^{3} J_{\mathrm{H}, \mathrm{H}}=2.0\right), 7.82(\mathrm{~d}, 2 \mathrm{H}$, $\left.{ }^{3} J_{\mathrm{H}, \mathrm{H}}=2.4\right), 7.99\left(\mathrm{~d}, 2 \mathrm{H},{ }^{3} J_{\mathrm{H}, \mathrm{H}}=2.0\right), 9.10(\mathrm{~d}, 2 \mathrm{H}$, $\left.{ }^{3} J_{\mathrm{H}, \mathrm{H}}=2.0\right)$. IR $\left(\mathrm{C}_{6} \mathrm{H}_{14}\right): v_{\mathrm{B}-\mathrm{H}}, 2481 \mathrm{w} ; v_{\mathrm{CO}}, 1985 \mathrm{~s}, 1966 \mathrm{~s}$ $\mathrm{cm}^{-1}$.

\subsection{Reaction of [TpRu(CO)(NCMe)Br] (1) with ${ }^{i} \mathrm{PrSH},{ }^{t} \mathrm{BuSH}$ and $\mathrm{Et}_{3} \mathrm{~N}$}

Compound 1 (0.262 g, $0.57 \mathrm{mmol}),{ }^{i} \mathrm{PrSH}$ (ca. $0.1 \mathrm{ml}$, $1.04 \mathrm{mmol}$ ), ${ }^{t} \mathrm{BuSH}$ (ca. $0.5 \mathrm{ml}, 4.40 \mathrm{mmol}$ ), $\mathrm{Et}_{3} \mathrm{~N}$ (ca. $0.5 \mathrm{ml}, 3.59 \mathrm{mmol})$ and 1,2-dimethoxyethane $(15 \mathrm{ml})$ were heated under reflux for $25 \mathrm{~h}$. The solvent and volatiles were then removed under vacuum, and the residue was taken up in a minimum amount of $\mathrm{CH}_{2} \mathrm{Cl}_{2}$. The products were separated by thin-layer chromatography using $\mathrm{CH}_{2} \mathrm{Cl}_{2}-\mathrm{C}_{6} \mathrm{H}_{14}$ mixed solvents to give 8.1

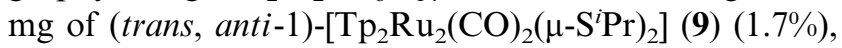

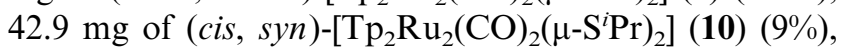

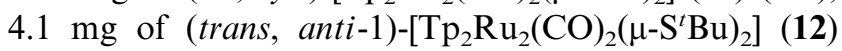
$(0.8 \%)$, and $4.6 \mathrm{mg}$ of (cis, anti-2)-[ $\mathrm{Tp}_{2} \mathrm{Ru}_{2}(\mathrm{CO})_{2^{-}}$ $\left.\left(\mu-\mathrm{S}^{i} \mathrm{Pr}\right)\left(\mu-\mathrm{S}^{t} \mathrm{Bu}\right)\right] \quad(\mathbf{1 5}) \quad(0.5 \%) . \quad$ (cis, anti-2)-[Tp $\mathrm{Tu}_{2} \mathrm{Ru}^{-}$ $\left.(\mathrm{CO})_{2}\left(\mu-\mathrm{S}^{i} \mathrm{Pr}\right)\left(\mu-\mathrm{S}^{t} \mathrm{Bu}\right)\right](\mathbf{1 5})$ : orange-yellow. Anal. Calc. 


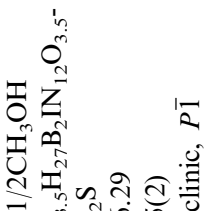

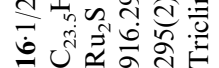

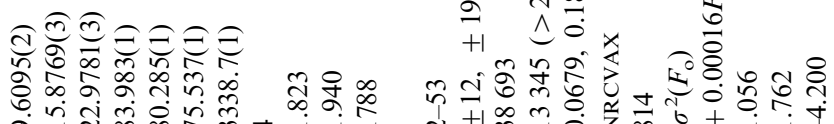

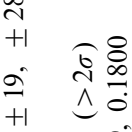

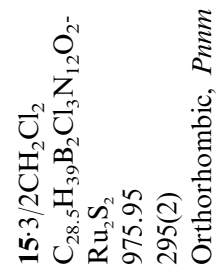

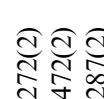

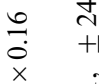

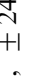

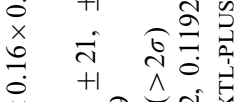

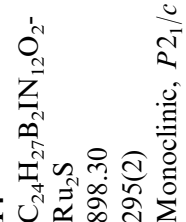

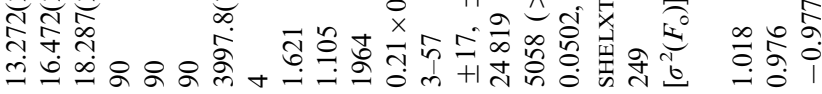

ב

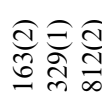

$\begin{array}{ll}x & 0 \\ 0 & +1 \\ 0 & 4 \\ 1 & 4\end{array}$

is $\infty$

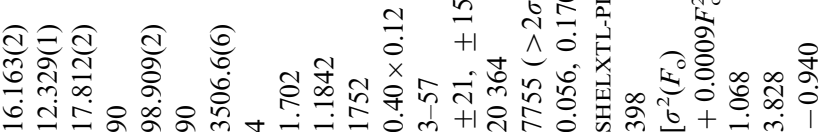

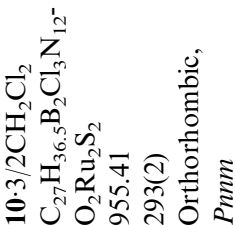

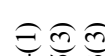

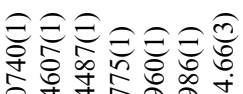

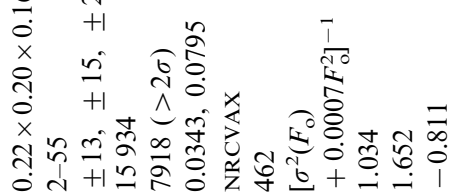

इ

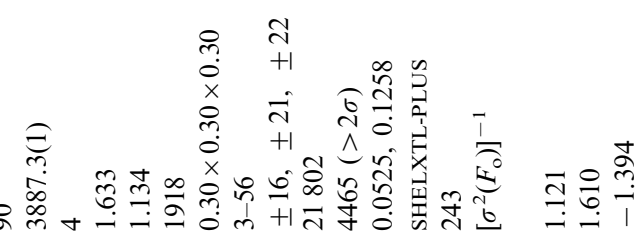

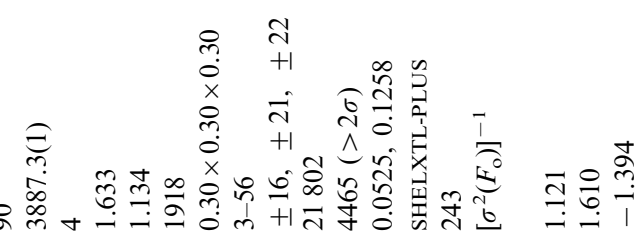

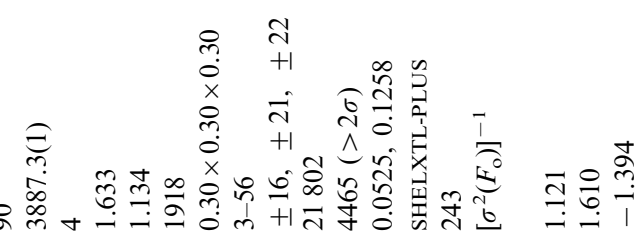

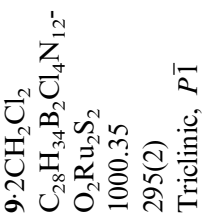

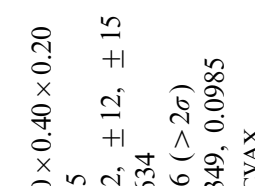

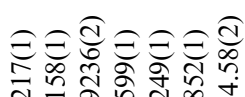

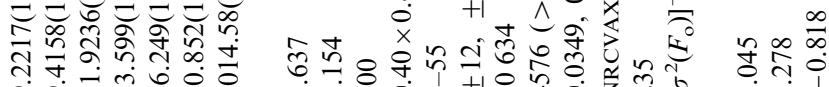

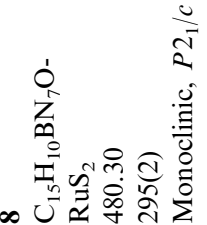

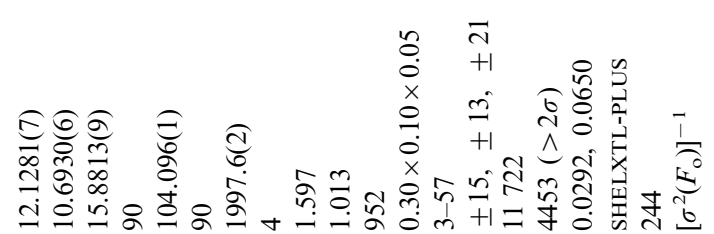

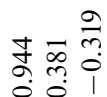

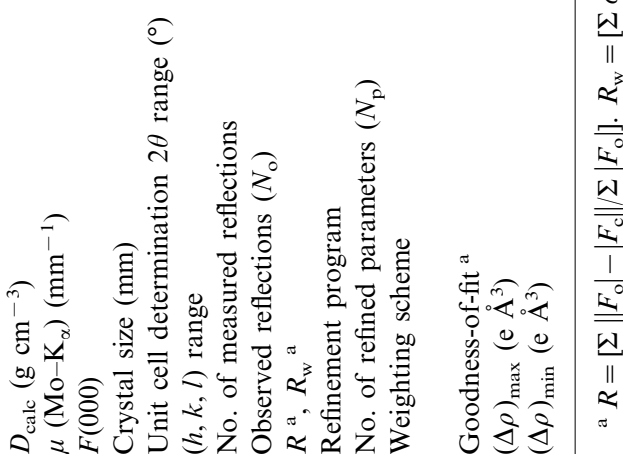


for $\mathrm{C}_{27} \mathrm{H}_{36} \mathrm{~B}_{2} \mathrm{~N}_{12} \mathrm{O}_{2} \mathrm{Ru}_{2} \mathrm{~S}_{2}$ : C, 38.22; $\mathrm{H}, 4.28 ; \mathrm{N}, 19.81$. Found: C, 38.06; H, 4.29; N, 19.77\%. ${ }^{1} \mathrm{H}-\mathrm{NMR}$ $\left(\mathrm{CDCl}_{3}\right): \delta 1.80(\mathrm{~s}, 9 \mathrm{H}), 1.37\left(\mathrm{~d}, 6 \mathrm{H},{ }^{3} J_{\mathrm{H}, \mathrm{H}}=6.8\right), 3.99$ $(\mathrm{m}, 1 \mathrm{H}), 6.27(\mathrm{t}, 2 \mathrm{H}), 6.31(\mathrm{t}, 2 \mathrm{H}), 6.37(\mathrm{t}, 2 \mathrm{H}), 7.68(\mathrm{~d}$, $\left.2 \mathrm{H},{ }^{3} J_{\mathrm{H}, \mathrm{H}}=2.0\right), 7.69\left(\mathrm{~d}, 2 \mathrm{H},{ }^{3} J_{\mathrm{H}, \mathrm{H}}=2.0\right) 7.73(\mathrm{~d}, 4 \mathrm{H}$, $\left.{ }^{3} J_{\mathrm{H}, \mathrm{H}}=2.4\right), 7.75\left(\mathrm{~d}, 2 \mathrm{H},{ }^{3} J_{\mathrm{H}, \mathrm{H}}=2.4\right), 8.55(\mathrm{~d}, 2 \mathrm{H}$, $\left.{ }^{3} J_{\mathrm{H}, \mathrm{H}}=2.0\right)$. IR $\left(\mathrm{C}_{6} \mathrm{H}_{14}\right): v_{\mathrm{B}-\mathrm{H}}, 2481 \mathrm{w} ; v_{\mathrm{CO}}, 1987 \mathrm{~s}, 1979 \mathrm{~s}$ $\mathrm{cm}^{-1}$.

\subsection{Reaction of (cis)-[Tp $\left.{ }_{2} R u_{2}(C O)_{2}(\mu-I)\left(\mu-S^{i} \mathrm{Pr}\right)\right]$ (11) with $\mathrm{Me}_{3} \mathrm{NO}$}

A solution of complex $11(8.9 \mathrm{mg}, 0.010 \mathrm{mmol})$ in $\mathrm{CH}_{2} \mathrm{Cl}_{2}(10 \mathrm{ml})$ was added with $\mathrm{Me}_{3} \mathrm{NO} \cdot 2 \mathrm{H}_{2} \mathrm{O}(51 \mathrm{mg}$, $0.46 \mathrm{mmol}$ ). The solution was stirred at r.t. for $1 \mathrm{~h}$, and the solvent was removed under vacuum. Recrystallization from $\mathrm{CH}_{2} \mathrm{Cl}_{2}-\mathrm{MeOH}$ gave $6.1 \mathrm{mg}$ of pure product 16. Yield $68 \%$. Anal. Calc. for $\mathrm{C}_{23} \mathrm{H}_{27} \mathrm{~B}_{2} \mathrm{IN}_{12} \mathrm{O}_{3} \mathrm{Ru}_{2} \mathrm{~S}$ : C, 30.62; H, 3.02; N, 18.63. Found: C, 30.59; H, 3.17; N, $18.54 \% .{ }^{1} \mathrm{H}-\mathrm{NMR}\left(\mathrm{CDCl}_{3}\right): \delta 0.89\left(\mathrm{~d}, 6 \mathrm{H},{ }^{3} J_{\mathrm{H}, \mathrm{H}}=6.8\right)$, $2.87(\mathrm{~m}, 1 \mathrm{H}), 6.16(\mathrm{t}, 2 \mathrm{H}), 6.20(\mathrm{t}, 2 \mathrm{H}), 6.43(\mathrm{t}, 2 \mathrm{H})$, $7.57\left(\mathrm{~d}, 2 \mathrm{H},{ }^{3} J_{\mathrm{H}, \mathrm{H}}=2.0\right), 7.63\left(\mathrm{~d}, 2 \mathrm{H},{ }^{3} J_{\mathrm{H}, \mathrm{H}}=2.0\right), 7.71$ $\left(\mathrm{d}, \mathrm{dH},{ }^{3} J_{\mathrm{H}, \mathrm{H}}=2.0\right), 7.79\left(\mathrm{~d}, 2 \mathrm{H},{ }^{3} J_{\mathrm{H}, \mathrm{H}}=2.0\right), 7.92(\mathrm{~d}$, $\left.2 \mathrm{H},{ }^{3} J_{\mathrm{H}, \mathrm{H}}=2.0\right), 8.84\left(\mathrm{~d}, 2 \mathrm{H},{ }^{3} J_{\mathrm{H}, \mathrm{H}}=2.0\right)$. IR $\left(\mathrm{CH}_{2} \mathrm{Cl}_{2}\right)$ : $v_{\mathrm{B}-\mathrm{H}}, 2491 \mathrm{w} ; v_{\mathrm{CO}}, 1979 \mathrm{~s}, 1945 \mathrm{~m} ; v_{\mathrm{SO}}, 943 \mathrm{~s} \mathrm{~cm}^{-1}$.

\subsection{Single-crystal $X$-ray diffraction studies}

Suitable single crystals of $8,9,10,12,14,15$, and 16 were grown from $\mathrm{CH}_{2} \mathrm{Cl}_{2}-\mathrm{MeOH}$ or $\mathrm{CH}_{2} \mathrm{Cl}_{2}-\mathrm{C}_{6} \mathrm{H}_{14}$ at r.t. and chosen for single crystal structure determinations. All the X-ray diffraction data were measured in frames with increasing $\omega$ (width of $0.3^{\circ}$ per frame) and with the scan speed at $20.00 \mathrm{~s} /$ frame on a Siemens SMART-CCD instrument, equipped with a normal focus and $3 \mathrm{~kW}$ sealed-tube X-ray source. Empirical absorption corrections were carried out using SHELXTLPC program for $\mathbf{8}, \mathbf{1 0}, \mathbf{1 4}$, and $\mathbf{1 5}$, and SADABS program for 9,12 and 16. These three structures were solved by the heavy-atom method and refined by a full-matrix least-squares procedure using NRCVAX [12]. Structures $8,10,14$, and 15 were solved by direct methods and refined by a full-matrix least-squares procedure using SHELXTL-PLUS [13]. Neutral atom scattering factors for non-hydrogen atoms and the values for $\Delta f^{\prime}$ and $\Delta f^{\prime \prime}$ described in each software [12,13] were used. The other essential details of single-crystal data measurement and refinement are listed in Table 1. In structure 10, atom $\mathrm{C}(13)$ was found to contain 0.5 occupancy and both $\mathrm{S}(2)-\mathrm{C}(13)$ and $\mathrm{C}(13)-\mathrm{C}(14)$ bond lengths were fixed with 1.808 and $1.525 \AA$, respectively, to allow a satisfactory refinement. Likewise, the $\mathrm{C}(17)-\mathrm{Cl}(3)$ bond length for one $\mathrm{CH}_{2} \mathrm{Cl}_{2}$ contained in structure 15 was also fixed with $1.89 \AA$. Several residual electron peaks with more than $1 \mathrm{e} \AA^{-3}$ were found with one peak close to atom $\mathrm{Cl}(2)$ in structure $\mathbf{9}$, one close to atom $\mathrm{S}(2)$ in structure $\mathbf{1 0}$, one close to atom $\mathrm{Ru}(1)$ in structure $\mathbf{1 2}$, one close to atom $\mathrm{S}(1)$ in structure $\mathbf{1 4}$, and one close to atom $\mathrm{I}(1)$ in structure 16. The one close to $\mathrm{S}(1)$ in $\mathbf{1 4}$ has the largest

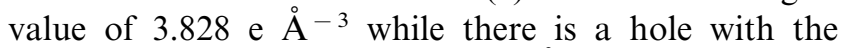

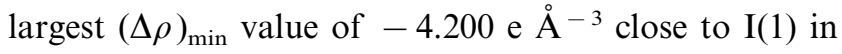
structure 16. Apparently both positions of the $\mathrm{S}(1)$ atom in $\mathbf{1 4}$ and the $\mathrm{I}(1)$ atom in $\mathbf{1 6}$ are slightly disordered.

\section{Conclusions}

In this work, we have demonstrated that $[\mathrm{TpRu}(\mathrm{CO})(\mathrm{MeCN}) \mathrm{X}] \quad(\mathrm{X}=\mathrm{Br}$ (1), I (2)), prepared readily from $\left[\mathrm{TpRu}(\mathrm{CO})_{2} \mathrm{X}\right]$, can serve as a good starting material leading to a variety of substituted products, including $[\mathrm{TpRu}(\mathrm{CO})(\mathrm{CNR}) \mathrm{X}] \quad(\mathrm{X}=\mathrm{Br}$, $\mathrm{R}=\mathrm{PhCH}_{2}$ (3); $\mathrm{X}=\mathrm{Br}, \mathrm{R}={ }^{t} \mathrm{Bu}(4) ; \mathrm{X}=\mathrm{I}, \mathrm{R}=\mathrm{PhCH}_{2}$ (5), $\left.\mathrm{X}=\mathrm{I}, \mathrm{R}={ }^{t} \mathrm{Bu}(\mathbf{6})\right),\left[\mathrm{TpRu}(\mathrm{CO})\left(\eta^{2}-\mathrm{S}_{2} \mathrm{CNR}_{2}\right)\right](\mathrm{R}=$

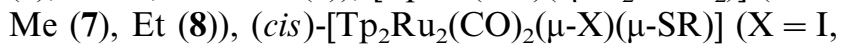
$\mathrm{R}={ }^{i} \mathrm{Pr} \quad(11) ; \mathrm{X}=\mathrm{Br}, \mathrm{R}={ }^{t} \mathrm{Bu} \quad(13) ; \mathrm{X}=\mathrm{I}, \mathrm{R}={ }^{t} \mathrm{Bu}$ (14)), (trans, anti-1)-[T $\left.\mathrm{Tp}_{2} \mathrm{Ru}_{2}(\mathrm{CO})_{2}\left(\mu-\mathrm{S}{ }^{i} \mathrm{Pr}\right)_{2}\right]$ (9), (cis, syn)- $\left[\mathrm{Tp}_{2} \mathrm{Ru}_{2}(\mathrm{CO})_{2}\left(\mu-\mathrm{S}^{i} \mathrm{Pr}\right)_{2}\right] \quad(\mathbf{1 0}), \quad$ (trans, anti-1)$\left[\mathrm{Tp}_{2} \mathrm{Ru}_{2}(\mathrm{CO})_{2}\left(\mu-\mathrm{S}^{t} \mathrm{Bu}\right)_{2}\right](\mathbf{1 2})$ and $\left(\right.$ cis, anti-2)- $\left[\mathrm{Tp}_{2} \mathrm{Ru}_{2^{-}}\right.$ $\left.(\mathrm{CO})_{2}\left(\mu-\mathrm{S}^{i} \mathrm{Pr}\right)\left(\mu-\mathrm{S}^{t} \mathrm{Bu}\right)\right](\mathbf{1 5})$. Compound 11 reacts with $\mathrm{Me}_{3} \mathrm{NO}$ to form stereo- and chemospecifically the first diruthenium sulfenate, $($ cis $)-\left[\mathrm{Tp}_{2} \mathrm{Ru}_{2}(\mathrm{CO})_{2}(\mu-\mathrm{I})(\mu-\right.$ $\left.\left.\mathrm{S}(\mathrm{O})^{i} \mathrm{Pr}\right)\right]$ (16) with the $\mathrm{S}=\mathrm{O}$ bond at the endo position with respect to carbonyls.

\section{Supplementary material}

Crystallographic data for the structural analysis has been deposited with the Cambridge Crystallographic Data Centre, CCDC no. 173316, 173454, 173315, $173455,173317,173456$, and 138612 for structures $\mathbf{8 , 9}$, 10, 12, 14, 15, and 16. Copies of this information may be obtained free of charge from The Director, CCDC, 12 Union Road, Cambridge CB2 1EZ, UK (Fax: + 441223-336033; e-mail: deposit@ccdc.cam.ac.uk or www:http://www.ccdc.cam.ac.uk).

\section{Acknowledgements}

Financial support for this work by the National Science Council of Republic of China (Contract NSC89-2113-M006-013) is gratefully acknowledged.

\section{References}

[1] S. Trofimenko, J. Am. Chem. Soc. 88 (1966) 1842.

[2] For the reviews on $\mathrm{Tp}$ complexes, see for example: (a) $\mathrm{S}$. Trofimenko, Chem. Rev. 93 (1993) 943;

(b) S. Trofimenko, Prog. Inorg. Chem. 34 (1986) 115. 
[3] (a) M.I. Bruce, D.N. Sharrocks, F.G.A. Stone, J. Organomet. Chem. 31 (1971) 269;

(b) M.I. Bruce, M.Z. Iqbal, F.G.A. Stone, J. Chem. Soc. Sect. A (1971) 2820;

(c) K. Hiraki, N. Ochi, T. Kitamura, Y. Sasada, S. Shinoda, Bull. Chem. Soc. Jpn. 55 (1982) 2356;

(d) M.M. de, V. Steyn, E. Singleton, S. Hietkamp, D.C. Liles, J. Chem. Soc. Dalton Trans. (1990) 2991;

(e) A.F. Hill, J. Organomet. Chem. 395 (1990) C35;

(f) N.W. Alcock, A.F. Hill, R.P. Melling, Organometallics 10 (1991) 3898.

[4] (a) M.A. Bennett, M.I. Bruce, T.W. Matheson, in: G. Wilkinson, F.G.A. Stone, E.W. Abel (Eds.), Comprehensive Organometallic Chemistry, vol. 4, Pergamon, Oxford, England, 1982, p. 691;

(b) M.A. Bennett, K. Khan, E. Wenger, in: E.W. Abel, F.G.A. Stone, G. Wilkinson (Eds.), Comprehensive Organometallic Chemistry II, vol. 7, Pergamon, Oxford, England, 1995, p. 473.

[5] M.D. Curtis, K.-B. Shiu, W.M. Butler, J.C. Huffman, J. Am. Chem. Soc. 108 (1986) 3335.

[6] C. Gemel, G. Trimmel, C. Slugovc, S. Kremel, K. Mereiter, R. Schmid, K. Kirchner, Organometallics 15 (1996) 3998.
[7] M. Tachikawa, J.R. Shapley, J. Organomet. Chem. 124 (1977) C129.

[8] K.-B. Shiu, S.-T. Lin, S.-M. Peng, M.-C. Cheng, Inorg. Chim. Acta 229 (1995) 153.

[9] K.-B. Shiu, S.-L. Wang, F.-L. Liao, M.Y. Chiang, S.-M. Peng, G.-H. Lee, J.-C. Wang, L.-S. Liou, Organometallics 17 (1998) 1790.

[10] (a) I. Font, R. Buonomo, J.H. Reienspies, M.Y. Darensbourg, Inorg. Chem. 32 (1993) 5897;

(b) M. Darensbourg, T. Tuntulani, J.H. Reibenspies, Inorg. Chem. 34 (1995) 6287;

(c) W.S. Allison, Acc. Chem. Res. 9 (1976) 293.

[11] M.D. Johnson, D. Nickerson, Inorg. Chem. 3 (1992) 3971.

[12] E.J. Gabe, Y. Le Page, J.-P. Charland, F.L. Lee, P.S. White, J. Appl. Crystallogr. 22 (1989) 384.

[13] (a) G.M. Sheldrick, SHELXTL-PLus Crystallographic System, release 4.21; Siemens Analytical X-ray Instruments: Madison, WL, 1991. ;

(b) Siemens Analytical X-ray Instruments Inc., Karlsruhe, Germany, 1991. 